\title{
CAN THE COMMON CORE COUNTER EDUCATIONAL INEQUITY? INTERNATIONAL LEGAL LESSONS ON CLOSING THE ACHIEVEMENT GAP
}

\begin{abstract}
Kristopher Frye*
I. INTRODUCTION

[T] he educational foundations of our society are presently being eroded by a rising tide of mediocrity that threatens our very future as a Nation and a people. What was unimaginable a generation ago has begun to occur--others are matching and surpassing our educational attainments. ${ }^{1}$ - A Nation at Risk, 1983

Thirty years have passed since the Reagan Administration's release of the Report to the Nation. ${ }^{2}$ Yet, despite its depiction of the status of the American educational system, it came as a shock to many when the 2009 Program for International Student Assessment (PISA) reaffirmed our "rising tide of mediocrity." 3 For the 2009 PISA, "the United States perform[ed] around the average in reading (rank 14) and science (rank 17) and below the average in mathematics (rank 25)" out of the thirty-four Organisation for Economic Co-operation and Development (OECD) countries. ${ }^{4}$ The 2012 PISA results worsened as U.S. rankings fell to seventeenth in reading, twenty-first in science, and twenty-sixth in
\end{abstract}

\footnotetext{
* Candidate for J.D., Indiana University Robert H. McKinney School of Law, 2015. M. Ed., University of Missouri-St. Louis, 2011. I would like to thank my family, including my wife, Carole, and my parents, T.R. and Mary Kay, for their unwavering support. I would also like to thank the staff of the Indiana International \& Comparative Law Review for their hard work and dedication.

1 The Nat'l Comm'n on Excellence in Educ., A Nation at Risk: The Imperative FOR Educational Reform 9 (1983) [hereinafter A Nation at Risk]. Despite the near cliché status of certain excerpts from A Nation at Risk, it is rare to find an educational reform piece referencing international educational systems that does not cite the report. E.g., Council on Foreign Relations, infra note 19, at 56; William H. Schmidt, Richard Houang \& Sharif Shakrani, International Lessons about National Standards 5 (2009); Neal McCluskey, Behind the Curtain: Assessing the Case fOR National CURriculum Standards 2 (Feb. 17, 2010). This Note will not break the trend because the statistics remain constant-U.S. education scores are mediocre.

${ }^{2}$ A Nation at Risk, supra note 1.

${ }^{3}$ Id.

4 Org. for Econ. Co-operation and Dev., Strong Performers and Successful REFORMERS IN EdUCATION: LESSONS FROM PISA FOR THE United STATES 26 (2011) [hereinafter OECD, Lessons from PISA 2012], available at http://dx.doi.org/10.1787/ 9789264096660-en.
}

http://dx.doi.org/10.18060/7909.0029 
mathematics out of the thirty-four OECD countries. ${ }^{5}$

In confronting the stagnant educational scores, the current manifestation of U.S. education reform is President Barack Obama's "Race to the Top” (RT3), an initiative compelling states to compete for \$4.35 billion by earning points based on education reform plans. ${ }^{6}$ Of RT3's five hundred possible points, fourteen percent (seventy points) can only be earned by demonstrating commitment "to adopting a common set of highquality standards," and "to improving the quality of assessments, evidenced by the State's participation in a consortium of States" that collectively develop and create standards and assessments. ${ }^{7}$ A consortium requires participation by a majority of all states to earn "high" points, which means that adopting the Common Core State Standards (CCSS) became the only option for earning the seventy points, or fourteen percent of total RT3 points. ${ }^{8}$

RT3 did not create CCSS. ${ }^{9}$ Instead, RT3 dangled the monetary carrot in front of states to promote the elevation of education standards. ${ }^{10}$ This led forty-eight states to collaborate and create "a voluntary set of rigorous college- and career-ready standards." 11

This shift toward nationalized standards is, at least in part, the product of researchers, legislators, and policymakers shifting their focus to discerning the best international approaches to educational achievement. ${ }^{12}$ Additionally, as international assessments continue to evolve and collect more demographic and socioeconomic information on participating

5 Org. for Econ. Co-operation and Dev., Strong Performers and Successful REFORMERS IN EdUCATION: LESSONS FROM PISA 2012 FOR THE UNITED STATES 26, (2013) [hereinafter OECD, Lessons from PISA 2012], available at http://www.oecd.org/pisa/key

findings/PISA2012_US\%20report_ebook(eng).pdf.

${ }^{6}$ White House, Education for K-12 Students, http://www.whitehouse.gov/issues/ education/k-12/race-to-the-top (last visited Oct. 20, 2013).

${ }^{7}$ U.S. Dep'T of Educ., Race to the Top Program Executive Summary 7 (2009), available at http://www2.ed.gov/programs/racetothetop/executive-summary.pdf. [hereinafter RT3 Executive Summary].

${ }^{8}$ U.S. DEP'T OF EDUC., RACE TO THE TOP Fund, SCORING Rubric 7, http://www2.ed.gov/ programs/racetothetop/scoringrubric.pdf (last visited Nov. 13, 2013). [hereinafter RT3 Scoring Rubric].

${ }^{9}$ See, White House, supra note 6.

${ }^{10} \mathrm{Id}$.

${ }^{11} I d$.

12 See generally Surpassing Shanghai: An Agenda for American Education Built ON THE WorlD's LEAding Systems (Marc S. Tucker ed.) (2011) [hereinafter Tucker]; Org. for Econ. Co-Operation and Dev., Strong Performers and Successful REFORMERS IN EdUCATION: LESSONS FROM PISA FOR THE UNITED STATES (2011), available at http://dx.doi.org/10.1787/9789264096660-en [hereinafter OECD, Lessons from PISA 2011];_Benjamin M. Superfine, The Courts And Standards-BAsed EDUCATION REFORM 25 (2008). 
students, a renewed focus has emerged over the equitable distribution of education opportunities and its impact on a country's overall scores. ${ }^{13}$ However, not every country with nationalized standards tops the international rankings. ${ }^{14}$ This is because no single policy represents a magic bullet; there is no quick fix in education reform. Despite support for systemwide reform ${ }^{15}$ and education leaders like Arnie Duncan, U.S. Secretary of Education, acknowledging, "High-performing education systems pursue a comprehensive set of reforms-not piecemeal," ${ }^{16}$ the U.S. education system is not designed for system-wide reform. ${ }^{17}$

As such, the mere existence of nationalized standards is not a reset button for educational mediocrity-it will not equate to an automatic vault in the international rankings. Instead, this Note argues that nationalized standards can establish a much-needed baseline for providing equity in U.S. education. This baseline does not represent a "one-size-fits-all”"18 education; it represents a quality control measure that collectively establishes a minimum expectation for learning outcomes. This Note argues that CCSS is a baseline or floor of expectations and that individual states determine where the ceiling belongs.

Nationalized standards cannot singlehandedly solve educational mediocrity, but they do have the potential to narrow the achievement gap by providing more equitable education opportunities. This, in turn, has the capability of raising our collective educational averages. This Note argues that by learning from the successes and failures of other countries that have implemented nationalized standards, the United States can create a system more receptive to CCSS and more capable of providing equitable education opportunities.

This Note addresses whether countries with nationalized standards provide more equitable distribution of educational opportunities. Further, whether the United States can raise their international education ranking by giving the same education opportunities received by students in

${ }^{13}$ OECD, Lessons from Pisa 2012, supra note 5, at 7.

14 See Alfie Kohn, Debunking the Case for National Standards: One-Size Fits-All Mandates and Their Dangers, EdUCATION WeEK, Jan. 14, 2010.

${ }^{15}$ E.g., Kathryn M. Doherty, U.S. Dept. Of Educ., EARly Implementation of the Comprehensive School Reform Demonstration (CSRD) Program 3 (2000) ("Research also shows that piecemeal, fragmented approaches to school reform rarely add up to a coherent, sustainable whole.”).

16 Arnie Duncan, Sec’y of Educ., Remarks at National Center on Education and the Economy National Symposium: Lessons from High-Performing Countries (May 24, 2011), http://www.ed.gov/news/speeches/lessons-high-performing-countries. See also Pearson, The Learning Curve: Lessons in Country Performance in Education 11 (2012).

${ }^{17}$ See Mo. v. Jenkins, 515 U.S. 70, 99 (1995) ("local autonomy of school districts is a vital national tradition.”).

${ }^{18}$ Kohn, supra note 14. 
Massachusetts and New Jersey, who score on par with the best in the world, to students in Louisiana and Mississippi who consistently score grade levels lower. ${ }^{19}$

To establish the potentiality of nationalized standards, this Note is divided into five parts. Part II of this Note will address the U.S. education ranking on international assessments and the state of education in the United States by comparing the educational rankings of states, socioeconomic data, and its relation to educational achievement. This provides a statistical backdrop for Part III, which provides an overview of the CCSS and explores the pros and cons of implementation. Part III also discusses the structure of the U.S. education system, state autonomy, and the tradition of local control over education. Lastly, it will address the role of the U.S. federal government and federal laws that shape local law and policy.

Part IV will analyze three international systems of law with nationalized standards that have varying degrees of specificity in their standards, and one system that accomplishes similar quality control without nationalized standards. This Note will identify common language and purpose behind statutes, ordinances, and decrees that exist in each country, despite varying degrees of federal involvement in education. The goal is to isolate the practices of countries that combine high performance while addressing and narrowing achievement gaps between the socioeconomically disadvantaged and the more affluent.

Finally, Part V argues that before CCSS, we did not hold the same expectations for all of our students or set equitable learning standards. ${ }^{20}$ Instead, our current educational rankings reflect our mediocre learning expectations. Further, the disparity of performance within states establishes that the United States acts in accordance with a belief that not all children can achieve at high levels. In particular, we believe the students in our poorest neighborhoods lack the capacity to achieve at high levels. This false paradigm directly correlates with our failure to climb the international educational rankings.

As such, this Note argues that nationalized standards represent a paradigmatic shift by the United States to raise the learning expectations for all students, regardless of state or ZIP code. This will produce long-term benefits for the U.S. international ranking by simply raising our country's overall achievement averages. The idea is that a rising tide can lift all

\footnotetext{
${ }^{19}$ Council on Foreign Relations, U.S. Education Reform and National Security, Independent Task Force Report No. 68, 17 (2012); See also, The Nation's Report Card, How are states performing? (2013), http://nationsreportcard.gov/reading\%5Fmath\%5F 2013/\#/state-performance (see State/National Results).

${ }^{20}$ See White House, Reforming No Child Left Behind, http://www.whitehouse.gov/ issues/education/k-12/reforming-no-child-left-behind (last visited Jan. 15, 2014).
} 
boats. ${ }^{21}$ To conclude, this Note will argue that successful implementation of CCSS can narrow the U.S. achievement gap, but its success is dependent on the existence of legislative acts or systemic fixtures that surround successful nationalized standards.

\section{THE STATUS OF AMERICAN EDUCATION ${ }^{22}$}

\section{A. International Rankings}

The most agreeable position in the debate on education reform is that "the United States has fallen to the middle of the pack among developed nations." ${ }^{23}$ Consider that in 1995, the United States was "tied for first in college and university graduation rates; by 2006 this ranking had dropped to $14^{\text {th }} .{ }^{24}$ While nodding your head in agreement is understandable, the statistics show more to the story. The reality is the tide of U.S. mediocrity on international assessments has been present since the 1960s, when the United States began routinely scoring in the bottom half of participating countries in mathematics and science. ${ }^{25}$ Despite this, the most recent PISA

21 See generally Jonathan C. Augustine \& Craig M. Freeman, Article: Grading the Graders and Reforming the Reform: An Analysis of the State of Public Education Ten Years After No Child Left Behind, 57 LOY. L. REV. 237 (2011); See also ERIC A. Hanushek, Paul E. Peterson \& Ludger Woesmann, Achievement Growth: International and U.S. State Trends in Student Performance 22 (2012).

22 This Note references four commonly cited assessments. The three international assessments include the Organisation for Economic Co-operation and Development's (OECD) [1] PISA (Programme for International Student Assessment); the International Association for the Evaluation of Educational Achievement's [2] TIMSS (Trends in International Mathematics and Science Study); and [3] PIRLS (Progress in International Reading Literacy Study). HANUSHEK ET AL., supra note 21, at 1. Lastly, the U.S. Department of Education's [4] NAEP (National Assessment of Educational Progress) provides a domestic statistical comparison between states through administration of a nationally uniform test. National Center for Education Statistics: National Assessment of Educational Progress (NAEP), http://nces.ed.gov/nationsreportcard/about/ (last visited Nov. 19, 2013). This Note focuses on PISA and NAEP because they provide more comprehensive coverage than TIMSS, which covers only math and science, and PIRLS, which only addresses literacy. See generally National Center for Education Statistics: National Assessment of Educational Progress (NAEP), http://nces.ed.gov/nationsreportcard/about/international.aspx (last visited Nov. 19, 2013).

${ }^{23}$ Jason Koebler, Editorial, U.S. Can Learn From Other Countries’ Education Systems, U.S. NEWS \& WORLD REPORT, (May 25, 2011), http://www.usnews.com/education/blogs/high-school-notes/2011/05/25/us-can-learnfrom-other-countries-education-systems.

24 McKinsey \& Co., Detalled Findings on the Economic Impact of the ACHIEVEMENT GAP In AMERICA's SCHOOLs 8 (2009).

${ }^{25}$ National Center for Education Statistics, International Mathematics and Science Assessment: What Have We LeArned? 65 (Jan. 1992), available at http://nces.ed.gov/pubs92/92011.pdf. 
scores and increased media attention have brought this mediocrity back into the spotlight.

After the 2009 PISA assessment, an OECD report found that "students in the United States do comparatively well at the very highest levels of reading proficiency (Levels 5 and 6), have an average share of top performers in science, but a below-average share of top performers in mathematics." 26 This means not all U.S. education is average and our highest performers can perform on par with the best the in the world. This means isolated parts of the United States are providing great education opportunities. However, even these high performers only buoy the total U.S. average to fourteenth out of thirty-four OECD countries. ${ }^{27}$

In contrast to the highest performers in reading, the 2009 PISA showed that "[e]ighteen per cent of 15-year-olds in the United States do not reach the PISA baseline Level 2 of reading proficiency," a level according to OECD where "students begin to demonstrate the reading competencies that will enable them to participate effectively and productively in life." 28 While nearly one in five U.S. fifteen-year-olds cannot demonstrate such competencies, in countries like "Shanghai-China, Hong Kong-China, Canada, Finland, and Korea, the proportion of poor performers is $10 \%$ or less." ${ }^{29}$ To put this in perspective, the National Center for Education Statistics (NCES) estimates that around 4.1 million fifteen-year-olds are currently enrolled in U.S. public schools. ${ }^{30}$ If eighteen percent of those U.S. students fail to meet the baseline PISA level two for reading, it means nearly 738,000 students every year are considered incapable of "participat[ing] effectively and productively in life." ${ }^{31}$ In 2012, the U.S. PISA reading scores improved slightly as $16.6 \%$ of students failed to meet level two, but twenty-six percent of U.S. fifteen-year-olds, or roughly 1,066,000 students, failed to meet baseline PISA level two in mathematics. $^{32}$

Inevitably, there is a strong correlation between socioeconomic

${ }^{26}$ OECD, Lessons from PISA 2011, supra note 4, at 31. The PISA assessment provides six categorical levels of achievement, with six being the highest and one being the lowest.

${ }^{27} \mathrm{Id}$. at 26. (As stated in the introduction, the United States ranks fourteenth in reading, seventeenth in science, and twenty-fifth in mathematics out of the thirty-four OECD participating countries.)

${ }^{28} I d$. at 29.

${ }^{29} \mathrm{Id}$.

${ }^{30}$ National Center for Education Statistics, Projections of Education Statistics to 2021 (Jan. 2012), available at http://nces.ed.gov/programs/projections/projections2021/tables/table_02CT.asp?referrer $=$ list $\% 22$.

${ }^{31}$ OECD, Lessons from PISA 2011, supra note 4, at 29.

${ }^{32} \mathrm{Id}$. at 24-25. 
background and educational achievement. ${ }^{33}$ Generally, "[m]ost of the students who perform poorly in PISA come from challenging socioeconomic backgrounds." 34 This translates into socio-economically advantaged student scores being higher by "the equivalent of nearly one year of schooling - than a less-advantaged student," on average for all OECD countries. ${ }^{35}$ However, the 2009 OECD report declared "socioeconomic disadvantage has a particularly strong impact on student performance in the United States." ${ }^{36}$ In fact, only six countries "show a larger impact of socio-economic background on reading performance than the United States." ${ }^{37}$ However, the United States, along with those six countries, "do not necessarily have a more disadvantaged socio-economic student intake than other countries; but socio-economic differences among students translate into a particularly strong impact on student learning outcomes." 38

The comparatively close relationship between the learning outcomes of students in the United States and socioeconomic background is therefore not simply explained by a more socioeconomically heterogeneous student population or society . . . mainly because socio-economic disadvantage translates more directly into poor educational performance in the United States than is the case in many other countries. ${ }^{39}$

Despite the correlation, a student's socio-economic background "is far from deterministic" because children in socioeconomically

\footnotetext{
${ }^{33}$ HANUSHEK ET AL., supra note 21, at 16.

${ }^{34}$ OECD, Lessons from PISA 2012, supra note 5, at 31.

35 Org. for Econ. Co-operation And Dev., PISA 2012 Results: Achieving EXCELLENCE THROUGH EQUITY 13, (2013), available at http://www.oecd.org/pisa/ keyfindings/pisa-2012-results-volume-ii.htm. [hereinafter OECD, Excellence through Equity].

${ }^{36}$ OECD, Lessons from PISA 2011, supra note 4, at 34.

${ }^{37}$ Id. (“Among OECD countries, only Hungary, Belgium, Turkey, Luxembourg, Chile and Germany show a larger impact of socio-economic background on reading performance than the United States.”).

${ }^{38} I d$. Looking at all the subjects including reading, the United States still ranks sixth from the bottom as of all OECD countries with "a more unequal distribution of income in their populations than the United States . . . only Panama, Chile, Peru, Argentina, Uruguay, and Turkey show a larger impact of socio-economic background on learning outcomes at school."

${ }^{39}$ Id. Like the 2009 PISA, the 2012 PISA reports corroborated this finding stating, "[i]n the United States, two students from different socio-economic backgrounds vary much more in their learning outcomes than is normally the case in these other countries;" OECD, Lessons from PISA 2012, supra note 12, at 29.
} 
disadvantaged schools have demonstrated they can achieve at high levels. ${ }^{40}$ Below the OECD average, $4.7 \%$ of U.S. students were considered resilient, meaning they come from the twenty-five percent most socio-economically disadvantaged students, but score in the top twenty-five percent in the world. ${ }^{41}$ Their success demonstrates that all students have the potential to achieve at the highest levels; even the most socio-economically disadvantaged students.

In conclusion, since the average of all U.S. scores dictates our ranking, our failure to provide equal and adequate educational opportunities to all students appears indicative of the U.S. education rankings. Despite the comparatively stronger association in the United States, a consistent association between student achievement and socio-economic background exists around the world. ${ }^{42}$ However, studies suggest that the varying levels of correlation mean, "differences in education policies might be an important element in differences in equality of opportunity." 43

\section{B. Domestic Education Outlook}

The educational opportunities American students receive is dependent upon their ZIP code. According to one study utilizing data from NAEP, PISA, PIRLS, and TIMSS, student achievement is "far from uniform across the United States . . . the variation across states was about as large as the variation among the countries of the world." 44 The result is ten individual states "outpaced the United States as a whole." 45 Achievement gaps exist

40 OECD, Lessons from PISA 2011, supra note 4, at 35. One of PISA's measures for identifying countries that provide equitable education is "resiliency." OECD, Excellence through Equity, supra note 35, at 58. According to PISA, "[r]esilient students are disadvantaged students (those in the bottom quarter of a country's or economy's distribution of socio-economic status) who perform in the top quarter of performance in all countries." Id. Naturally, a country with a greater portion of their most disadvantaged students performing at elite levels is evidence of equitable education opportunities. However, the number of variables in the selection criteria for being considered resilient makes goals based on resiliency percentages challenging to measure or target impactful policies. The criteria are derived from the PISA index of economic, social, and cultural status (ESCS). The ESCS is based on the "International Socio-Economic Index of Occupational Status (ISEI); the highest level of education of the student's parents, converted into years of schooling; the PISA index of family wealth; the PISA index of home educational resources; and the PISA index of possessions related to "classical" culture in the family home." ORG. FOR ECON. CoOPERATION AND DEV., Glossary of Statistical Terms, http://stats.oecd.org/glossary/ detail.asp?ID=5401 (last visited Jan. 15, 2014) [hereinafter ESCS Variance].

${ }^{41} I d$.

42 HANUSHEK ET AL., supra note 21, at 17.

${ }^{43} \mathrm{Id}$.

${ }^{44}$ Id. at VII.

${ }^{45} I d$. 
not just between the rich and poor or majority and minority populations; achievement gaps exist between individual states. ${ }^{46}$ Because some states are "routinely out-educating others ... this means that students growing up in California or Nevada, for example, cannot expect the same quality of education as their counterparts in Massachusetts or Montana." ${ }^{47}$

A comparison [of states] suggests that in reading, public schools in the northeast of the United States would perform at 510 PISA score points - 17 score points above the OECD average . . . followed by the midwest with 500 score points . . . the west with 486 score points . . . and the south with 483 score points. ${ }^{48}$

The observable conclusion is the existence of great variability between states and regions in their ability to deliver educational outcomes. ${ }^{49}$

\section{The Impact of Socioeconomic Status}

From an international perspective, the 2003 PISA showed that "[l]ow and high socio-economic status correspond to the 25th and 75th percentile." ${ }^{50}$ The correlation between a family's socioeconomic status and a child's ability to be successful in school "undoubtedly contribute[s] to the increasing stratification in who attends and graduates from college, limiting economic and social mobility and serving to perpetuate the gap between rich and poor." ${ }^{51}$ The correlation also means "young people born to poor parents are now less likely to perform well in school and graduate from college than their better-off peers, and they are increasingly less likely to rise out of poverty." ${ }^{52}$ Without viable means to social mobility, the problem becomes more pronounced considering the United States ranks "second highest in child poverty among the world's 'richest' 35 countries," or twenty-two percent of all U.S. children. ${ }^{53}$

${ }^{46}$ See Council on Foreign Relations, supra note 19, at 17.

${ }^{47} \mathrm{Id}$.

48 OECD, Lessons from PISA 2011, supra note 4, at 26. Report stated that PISA did not directly measure individual state performance and that the sampling of each state resulted in scores associated with considerable measures of error. However, the purpose of including these statistics is not to analyze individual state scores on PISA, but instead to illustrate that regardless of each individual state's estimated measure of performance, disparity in the range of scores within the United States is present.

${ }^{49} \mathrm{Id}$.

${ }^{50}$ HANUSHEK ET AL., supra note 1, at Fig. 9.

${ }^{51}$ Educational Testing Service, Poverty and Education: Finding the Way FORWARD 2 (2013).

52 Council on Foreign Relations, supra note 19, at 12-13.

53 Educational Testing Service, supra note 51, at 7. 
Educational inequity "hurt[s] minority and economically disadvantaged students the most." 54 Even though America is a diverse nation, "many other countries have the same degree of diversity as the United States." 55 The problem is that "socioeconomic disadvantages in the United States are more closely linked with poor academic performance than in other countries." ${ }^{56}$ This illustrates that in other countries, a student's socioeconomic status is not indicative of their educational outcomes. While the impact of poverty is great, it is not deterministic because studies show that even students in the poorest neighborhoods can achieve with the best in the world. ${ }^{57}$ Poverty may make the road more challenging, but educational equity creates the foundation for social mobility.

\section{Economic Impact}

The impact education has on the economy is well documented. ${ }^{58}$ President Barack Obama's current educational platform acknowledges that "[b]ecause Economic Progress and educational achievement are inextricably linked, educating every American to graduate from high school prepared for college and for a career is a national imperative." 59

Studies show that "cognitive skills are closely related to the long-run growth rates for countries," and that "relatively small improvements in the skills of a nation's labor force can have very large effects on long-run economic well-being." 60 This is because a country's distribution of income correlates with the variations in skills of a labor force. ${ }^{61}$ This means educational achievement directly impacts the economic well-being of every country in the world. ${ }^{62}$ The United States' Council on Foreign Relations stated, "even in the midst of high unemployment rates, business owners are struggling to find graduates with sufficient skills in reading, math, and science to fill today's jobs." 63 The reality is students are competing for employment as part of a global workforce, and "[p]oorly educated and semi-skilled Americans cannot expect to effectively compete for jobs against fellow U.S. citizens or global peers, and are left unable to fully

\footnotetext{
${ }^{54}$ CounCil On Foreign Relations, supra note 19, at 14-15.

${ }^{55} \mathrm{Id}$. at 25.

${ }^{56} \mathrm{Id}$.

${ }^{57}$ OECD Lessons from PISA 2011, supra note 4, at 35.

58 See generally, HANUSHEK ET AL., supra note 21; see also COUNCIL ON FOREIGN RELATIONS, supra note 19, at IX.

${ }^{59}$ White House, Education for K-12 Students, http://www.whitehouse.gov/issues/ education/k-12 (last visited Oct. 20, 2013).

${ }^{60}$ HANUSHEK ET AL., supra note 21, at 46.

${ }^{61} \mathrm{Id}$. at 53.

${ }^{62} I d$.

${ }^{63}$ Council on Foreign Relations, supra note 19, at IX.
} 
participate in and contribute to society." ${ }^{64}$ As PISA demonstrated, if eighteen percent of fifteen year-olds do not reach a level that will "enable them to participate effectively and productively in life," ${ }^{\circ 5}$ how can they expect to compete for a job in the global market?

In a global economy where the most valuable skill you can sell is your knowledge, a good education is no longer just a pathway to opportunity - it is a pre-requisite. Right now, three-quarters of the fastest-growing occupations require more than a high school diploma. And yet, just over half of our citizens have that level of education. We have one of the highest high school dropout rates of any industrialized nation. And half of the students who begin college never finish. This is a prescription for economic decline, because we know the countries that out-teach us today will outcompete us tomorrow. - President Barack Obama ${ }^{66}$

The Council on Foreign Relations concluded that “America's young citizens are simultaneously confronted with growing economic inequalities and an increasingly global and competitive world, elementary and secondary (K-12) schools are failing to provide the promised opportunity." ${ }^{\circ 7}$ This represents the driving force behind education reform because "[a] highly educated workforce increases economic productivity and growth." ${ }^{68}$ However, a highly educated workforce can only exist if equitable educational opportunities are given to everyone, not just those with a higher socioeconomic status.

\section{THE PURSUIT OF EQUITY IN AMERICAN EDUCATION}

Our forefathers recognized education as a prerequisite to social mobility and the preservation of liberty ${ }^{69}$ In 1779 , Thomas Jefferson stated that "the most effective means of preventing [societal degeneracy] would be, to illuminate, as far as practicable, the minds of the people at large."70 Jefferson stated that "without regard to wealth, birth or other accidental

${ }^{64} I d$. at 8.

65 OECD, Lessons from PISA 2011, supra note 4, at 29.

${ }^{66}$ President Barack Obama, Address to Joint Session of Congress (Feb. 24, 2009).

${ }^{67}$ Council on Foreign Relations, supra note 19, at 3.

${ }^{68} \mathrm{Id}$. at 8.

69 See generally, Kern Alexander \& M. David Alexander, American PubliC SCHOOL LAW 29-32 (8th ed. 2012).

70 Id. at 31. (quoting From the Works of Thomas Jefferson, vol. 2, 414-26 (Paul Leicester ed., New York: G.P. Putnam's Sons, 1904, available at http://www.llmcdigital.org/titleresults.aspx searchtype=0\&set=61088\&volume=\&part= \&page $=)$ ). 
condition . . . those of their children whom nature hath fitly formed and disposed to become useful instruments for the public, it is better that such should be sought and educated at the common expense of all."71

In 1765, John Adams stated, "Liberty cannot be preserved without a general knowledge among the people," and that "the preservation of the means of knowledge among the lowest ranks is of more importance to the public than all the property of all the rich men in the country."72 Further, in George Washington's farewell address, he called for the promotion of "institutions for the general diffusion of knowledge," as an "object of primary importance." 73

The words of these founding fathers undoubtedly contributed to the establishment of the common public school systems paid through public taxation. ${ }^{74}$ However, the high prevalence of education inequity appears in opposition to their intentions, whether those intentions were economic, social, or equity based.

\section{A. Brief History Standards-Based Reform}

One of the first standards-based reform movements began in 1892, when the National Education Association's (NEA) Committee of Ten "issued a report calling for new curricular standards for all students." 75 The standards were not adopted, but the idea reappeared in 1926, when the College Entrance Examination Board (CEEB) initiated the Scholastic Aptitude Test (SAT) to "predict readiness of high school students for college." ${ }^{76}$ While the "SAT was not designed to guide school standards. It likely constituted an important influence on what students were taught."77 After all, if your students are scoring poorly on a test that decides whether they can be successful in college, the likely result is an alteration in your standards or teaching methodologies.

As previously stated, the United States began routinely scoring in the bottom half of participating countries in mathematics and science in the

${ }^{71}$ Id.

72 Id. at 31 (quoting Works of John Adams 456, Dissertation on the Canon and Feudal Law (C.F. Adams ed. 1851)).

${ }^{73} \mathrm{Id}$. at 30.

${ }^{74} \mathrm{Id}$. at 29-32.

75 SUPERFINE, supra note 12 , at 23.

${ }^{76}$ Id.

${ }^{77}$ Id. Cf. Valerie Strauss, Why I ppose Common Core standards: Ravitch, WASH. PosT (Feb. 26, 2013, 7:00AM), http://www.washingtonpost.com/blogs/answersheet/wp/2013/02/26/why-i-oppose-common-core-standards-ravitch/. Despite both CCSS and NAEP setting forth standards that are or will be aligned to assessments, Diane Ravitch states that CCSS can be distinguished from NAEP because "NAEP gives specifications to test-developers, not to classroom teachers.” 
1960s. ${ }^{78}$ Also during that time, student SAT and NAEP scores began to drop, which placed greater focus on the quality of schools being provided. ${ }^{79}$ One effect of this focus was the passage of the Elementary and Secondary Education Act of 1965 (ESEA), which targeted the equitable distribution of education opportunities. ${ }^{80}$ While ESEA did not initiate standards-based reform, it provided "billions of dollars of grants for the compensatory education of economically disadvantaged students." 81

In the 1970s, education reformists began criticizing "unjustified social promotion and low academic standards," which resulted in accountability measures like minimum competency tests (MCT). ${ }^{82}$ This standardization of learning expectations resulted in "36 states adopt[ing] some form of MCT" by $1979 .{ }^{83}$

Standards-based reform began building greater momentum at the Charlottesville Education Summit in 1989, when President George H. W. Bush "forged a bipartisan agreement about the need for national performance goals for students." ${ }^{4}$ The National Governor's Association, with President G.H.W. Bush, "explicitly indicated that a new 'Federal-State Partnership' would need to be developed" to meet the goals set at the summit. ${ }^{85}$ Some argue that "[t]he most significant aspect of the Summit was not the statement of goals, but rather the strong message from fifty-one chief executives that the time had come for uniform national standards." 86 President G. H. W. Bush was unable to sign into law the "creation of worldclass standards in five core subjects" ${ }^{87}$ laid out in America 2000: Excellence

\footnotetext{
${ }^{78}$ National Center for EduCAtion Statistics, supra note 25, at 65.

${ }^{79}$ SUPERFINE, supra note 12, at 24.

80 Elementary and Secondary Education Act of 1965, Pub. L. No. 89-10 § 201, Declaration of Policy. Most ESEA reauthorizations echo the education reform around the principle of equitable education opportunities. The first Title of the Improving America's Schools Act of 1994 is "Helping Disadvantaged Children Meet High Standards," and the goal was to provide "a fair and equal opportunity" to obtain a "high-quality education.” IASA, infra note 89. This language is nearly identical to No Child Left Behind, which aimed to provide a "fair, equal, and significant opportunity to obtain a high-quality education.” [Insert infra to NCLB.]

81 Benjamin Michael Superfine, Stimulating School Reform: The American Recovery and Reinvestment Act and the Shifting Federal Role in Education, 76 Mo. L. REv. 81, 87 (2011).

${ }^{82}$ SuPERFINE, supra note 12, at 24.

${ }^{83}$ Id.

${ }^{84} I d$. at 26.

${ }^{85} \mathrm{Id}$.

86 Michael Heise, Goals 2000: Educate America Act: The Federalization and Legalization of Educational Policy, 63 FordHAm L. Rev. 345, 355 (1994).

87 Superfine, supra note 12, at 33 (internal quotations removed). Further, Superfine states that concerns "about the institution of school choice and voluntary national standards and tests" resulted in the bill not being passed. (emphasis added).
} 
in Education Act, ${ }^{88}$ but the attempt paved the way for President Bill Clinton's standards-based reform legislation. ${ }^{89}$

One stated purpose of President Clinton's Goals 2000 was "to promote the development and adoption of a voluntary national system of skill standards and certifications," ${ }^{90}$ but states were ultimately incentivized to develop their own individual state standards. ${ }^{91}$ The Act also created the National Education and Standards Improvement Council (NESIC), a federal review board that provided comparative analysis of state standards against the voluntary national content standards."92 To compliment Goals 2000, Clinton passed another bipartisan effort with the Improving America's Schools Act of 1994 (IASA), a reauthorization of the ESEA of 1965, which attempted to improve equity in education opportunities by conditioning "the receipt of its funds upon the development of standards and assessment systems in each state." 93 The purpose of IASA was twofold; get each state to create standards that applied to all students and then create assessments measuring student performance on those standards. ${ }^{94}$ Lastly, the IASA introduced schools to measuring adequate yearly progress (AYP), but meeting AYP was not a condition of receiving funds. ${ }^{95}$ The IASA was unable to realize its initial purpose as President Clinton, facing a strong push by conservative groups to stop NESIC and the federal influence over education, signed a 1996 appropriation bill that eliminated the state submission requirements under Goals 2000 and the funding for NESIC. ${ }^{96}$

It was not long before the standards-based reform movement blurred the respective Democratic and Republican party lines again. ${ }^{97}$ In 2002, President George W. Bush passed No Child Left Behind (NCLB), "[a]n act to close the achievement gap with accountability, flexibility, and choice, so

${ }^{88}$ America 2000: Excellence in Education Act, H.R. 2460, 102nd Congr. (1991).

${ }^{89}$ See, Goals 2000: Educate America Act, H.R. 1804, 103rd Cong. (1994) [hereinafter Goals 2000]; See Improving America's Schools Act, H.R. 6, 103rd Cong. (1994) [hereinafter IASA].

90 Id. at 89.

${ }^{91} I d . \S 306(\mathrm{c})$.

${ }^{92} I d . \S 211$.

${ }^{93}$ Id. $\S 1111(\mathrm{~b})(6)(\mathrm{A})$. “A State that does not have challenging State content standards and challenging State student performance standards, in at least mathematics and reading or language arts, shall develop such standards within one year of receiving funds under this part after the first fiscal year for which such State receives such funds after the date of enactment of the Improving America's Schools Act of 1994." See also SUPERFINE, supra note 12, at 34-35.

${ }^{94}$ IASA, supra note 91, § 1111(b)(2); See also MARgaret E. GoertZ, The Federal Role in Defining “Adequate Yearly Progress:” The Flexibility/Accountability TRADE-OFF 1-2 (2001), available at http://www.cpre.org/sites/default/files/research report/808_cep01.pdf; See generally Augustine et al., supra note 21, at 248.

${ }^{95}$ IASA, supra note 91, § 1111(b)(2); See also GoERTZ, supra note 94, at 1-2.

96 SUPERFINE, supra note 12, at 34-35.

${ }^{97}$ Id. at 34. 
that no child is left behind." "98 Another reauthorization of the ESEA of 1965, the purpose of NCLB was "to ensure that all children have a fair, equal, and significant opportunity to obtain a high-quality education and reach, at a minimum, proficiency on challenging State academic achievement standards and state academic assessments (emphasis added)." 99 NCLB built on the requirements of IASA, but included in particular, one critical difference - federal education funding would be contingent on states making AYP on these "challenging academic achievement standards and state academic assessments." ${ }^{100}$ Under NCLB, states were required to create standards, assessments, and then report their demonstrated AYP in order to receive federal funding. ${ }^{101}$

Problems quickly arose under NCLB, as the law allowed states to

98 No Child Left Behind Act of 2001, Pub. L. No. 107-110, 115 Stat. 1425. Additionally, the phrase achievement gap "refers to any significant and persistent disparity in academic performance or educational attainment between different group of students, such as white students and minorities, for example, or students from higherincome and lower-income households . . . achievement gap refers to outputs-the unequal or inequitable distribution of educational results and benefits.” Great Schools P'ship, The GlOSSARY Of EdUCATION REFORM, http://edglossary.org/achievement-gap/ (last updated Dec. 19, 2013).

99 The Elementary and Secondary Education Act of 1965 was the first federal education law with a specific of providing aid to socioeconomically disadvantaged children. Elementary and Secondary Education Act of 1965, Pub. L. No. 89-10 § 201, Declaration of Policy; No Child Left Behind Act of 2001, Pub. L. No. 107-110, 115 Stat. 1425; 20 USCS § 6301 (emphasis added). This purpose can be accomplished by (1) ensuring that high-quality academic assessments, accountability systems, teacher preparation and training, curriculum, and instructional materials are aligned with challenging State academic standards so that students, teachers, parents, and administrators can measure progress against common expectations for student academic achievement; (2) meeting the educational needs of low-achieving children in our Nation's highest-poverty schools, limited English proficient children, migratory children, children with disabilities, Indian children, neglected or delinquent children, and young children in need of reading assistance; (3) closing the achievement gap between high- and low-performing children, especially the achievement gaps between minority and nonminority students, and between disadvantaged children and their more advantaged peers; (4) holding schools, local educational agencies, and States accountable for improving the academic achievement of all students, and identifying and turning around low-performing schools that have failed to provide a high-quality education to their students, while providing alternatives to students in such schools to enable the students to receive a high-quality education; (5) distributing and targeting resources sufficiently to make a difference to local educational agencies and schools where needs are greatest; (6) improving and strengthening accountability, teaching, and learning by using State assessment systems designed to ensure that students are meeting challenging State academic achievement and content standards and increasing achievement overall, but especially for the disadvantaged.

100 See generally Superfine, supra note 81, at 90-91; SuPERFINE, supra note 12, at 47.

${ }^{101} I d$. 
define what qualified as meeting AYP. ${ }^{102}$ The result was AYP becoming a mobile standard for any state wishing to ensure compliance with NCLB's AYP requirements. According to the White House, NCLB "created incentives for states to lower their standards." 103 Additionally, because each state had the discretion to set their own proficiency standards, this meant there were fifty different sets of standards and assessments for what students needed to know to be successful in each grade. Inevitably, "state proficiency standards have varied widely." "104 The result was students scoring "below the tenth percentile nationally" could be considered proficient in some states, while "[i]n other states, meanwhile, they had to reach the seventy-seventh percentile to wear the same label.”105

In 2006, the Thomas B. Fordham Foundation conducted a nationwide assessment of individual state standards. ${ }^{106}$ The nation's average grade for the standards was "a disappointing " $\mathrm{C}$-minus" in 2000 and remains so today." ${ }^{107}$ Further, the report found that "[t]wo-thirds of the nation's K-12 students attend schools in states with C-, D-, or F-rated standards.” 108 The only states receiving A's were California, Indiana, and Massachusetts. ${ }^{109}$

In 2009, Education Next conducted a comparative analysis between state standards and NAEP standards ${ }^{110}$ and found that:

[O]nly five states-Massachusetts, Missouri, Washington, Hawaii, and New Mexico-set their proficiency standards at levels roughly equivalent to the NAEP level of proficiency. Meanwhile, Tennessee, Nebraska, Alabama, and Michigan, the states with the lowest proficiency standards, set them closer to the NAEP basic level. ${ }^{111}$

\footnotetext{
10220 U.S.C. § 6311(b)(2)(B); § 6311(b)(2)(C).

${ }^{103}$ White House, Reforming No Child Left Behind, supra note 20.

104 HANUSHEK ET AL., supra note 21, at 9; See also Superfine, supra note 81, at 91.(highlighting the inconsistencies of NCLB implementation across the U.S., stating, "[p]erhaps most notably, the quality of the standards that states have developed has been varied and sometimes quite low. Similarly, states have implemented a range of different assessments to satisfy NCLB requirements, and many of these assessments have failed to be consistently aligned with state standards.”)

105 Chester E. Finn Jr., Liam Julian \& Michael Petrilli, The State of State Standards, THOMAs B. FordHAM Foundation (2006).

${ }^{106} I d$.

${ }^{107} I d$. at 6.

${ }^{108} \mathrm{Id}$.

${ }^{109}$ McCluskey, supra note 1 , at 7.

${ }^{110}$ Paul E. Peterson \& Carlos X. Lastra-Anadon, State Standards Rise in Reading, Fall in Math, EducationNeXt Vol. 10, No. 4 (Fall 2010), http://educationnext.org/statestandards-rising-in-reading-but-not-in-math/.

${ }^{111}$ HAnUSheK ET AL., supra note 21, at 9 (citing Peterson \& Lastra-Anadon , supra note 110).
} 
To put this in context, NAEP divides scores into three categories: Basic (partial mastery), Proficient (solid academic performance), and Advanced (superior performance). ${ }^{112}$ This meant four states did not expect students to demonstrate solid academic performance or in other terms, four states did not even expect mediocrity. Even the states with the most stringent standards only require solid academic performance. ${ }^{113}$ Further, the 2013 NAEP reading results showed only thirty-two percent of eighth grade students scored proficient, while forty-two percent scored Basic and twenty-two percent scored Below Basic. ${ }^{114}$ It is understandable to see how our international PISA, PIRLS, and TIMSS assessment results mirror our mediocre student learning expectations defined by NAEP. This recipe for mediocrity was summarized by the 2012 Council on Foreign Relations, which stated, "[f]or decades, each U.S. state and many cities set unique standards. The patchwork of learning standards and curricula is a prime example of the United States' failure to provide a strong, uniform K-12 education to all children." 115 The reality is "[t]he differences in educational standards and opportunities across the United States put students who were simply born in the 'wrong' neighborhood or state at a significant disadvantage.”116

\section{B. Arriving at the Common Core}

President Obama's standard-based reform arrived in the form of Race to the Top (RT3), an initiative compelling states to compete for $\$ 4.35$ billion by earning points based on education reform plans. ${ }^{117}$ As previously noted, adoption of CCSS became the only way to reach seventy of the possible five hundred points in a state's RT3 application. ${ }^{118}$ Strictly speaking, only forty points were awarded for adoption of CCSS, while the remaining thirty points required "working toward jointly developing and implementing common, high-quality assessments," aligned to the CCSS. ${ }^{119}$

Ultimately, adoption of CCSS is accompanied by the voluntary adoption of a common assessment aligned to CCSS. ${ }^{120}$ Reiterating the

112 National Center for Education Statistics: NAEP Achievement Levels, http://nces.ed.gov/nationsreportcard/achievement.aspx\#table (last visited Jan. 15, 2014). ${ }^{113} I d$.

114 National Center for Education Statistics, The Nation's Report Card, A First LOOK: 2013 MATHEMATICS AND READING 7, available at http://nces.ed.gov/pubsearch/ pubsinfo.asp?pubid=2014451 (last visited Jan. 15. 2014).

115 Council on Foreign Relations, supra note 19, at 36.

${ }^{116} \mathrm{Id}$. at 17.

${ }^{117}$ White House, Education for K-12 Students, supra note 6.

${ }^{118}$ RT3 Scoring Rubric, supra note 8, at 7.

${ }^{119}$ Id.

120 Adopting the CCSS does not mean a state is also required to use the common assessment. For example, Georgia adopted the CCSS, but chose not to use the common 
point, RT3 did not create the CCSS. Instead, RT3 incentivized to states elevate education standards. This led to the collaborative effort of fortyeight states to create "a voluntary set of rigorous college and career ready standards." 121

\section{Structure of American Education}

In 1979, Department of Education Organization Act created the Department of Education (DOE) and provided a framework for the department's operation. ${ }^{122}$ Congress' express intention was "to protect the rights of State and local governments . . . in the areas of educational policies ... and improve the control of such governments and institutions over their own educational programs and policies." ${ }^{23}$ The law provides that the

assessment. Wayne Washington, Georgia decides against offering 'Common Core' standardized test, AtlantA Journal-Constitution (Jul. 22, 2013, 3:54 PM), http://www.ajc.com/news/news/breaking-news/georgia-decides-against-offeringcommon-core-stand/nYzDr/.

121 White House, Education for K-12 Students, supra note 6. In analyzing the implementation of CCSS, it is important to note that curriculum and standards are fundamentally different. Standards represent end of the year goals. Curriculum represents a day-to-day plan for each instructional day. E.g., Kristy Campbell, Common Core Facts of the Day: Standards v. Curriculum, The EdFly Blog (Jun. 3, 2013), http://excelined.org/2013/06/common-core-fact-of-the-day-standards-v-curriculum/. An example of a standard is "Add within 100, including adding a two-digit number and a one-digit number.” Common Core State Standards Initiative, Mathematics; Grade 1; Numbers \& Operations in Base Ten, CCSS.Math.Content.1.NBT.C.4, http://www.corestandards.org/Math/Content/1/NBT (last visited Jan 11, 2014). This means "we expect students to know that $2+2=4$, and why." Kristy Campbell, Common Core Facts of the Day: Standards v. Curriculum, The EdFly Blog (Jun. 3, 2013), http://excelined.org/2013/06/common-core-fact-of-the-day-standards-v-curriculum/.

Conversely, "curriculum is the program created by local school districts to teach students to learn that $2+2=4$, and why." Id. This means CCSS is not a curriculum because it establishes learning goals, but does not provide for or mandate any method for reaching those goals. Instead, it is a "set of shared expectations for what students will learn and be able to do." CounCiL ON FOREIGn Relations, supra note 19, at 36-37. See Learn More. Go Further., Frequently Asked Questions, Resources, and Fact Sheets, http://commoncore.learnmoregofurther.org/common-core-news-media/common-corestate-standards-frequently-asked-questions/(last visited Oct. 15, 2014) ("[CCSS] is a state-led effort that established a single set of clear educational standards for kindergarten through 12th grade in English language arts and mathematics.”). In other words, "Standards are the end. Curriculum is the means." Kristy Campbell, Common Core Facts of the Day: Standards v. Curriculum, The EdFly Blog (Jun. 3, 2013), http://excelined.org/2013/06/common-core-fact-of-the-day-standards-v-curriculum/.

122 Department of Education Organization Act, Pub. L. No. 96-88 93 Stat. 668 (1979).

12320 U.S.C.A. § 3403 (West 1979) (“(a) Rights of local governments and educational institutions.

It is the intention of the Congress in the establishment of the Department to protect the rights of State and local governments and public and private educational institutions in the areas of educational policies and administration of programs and to strengthen and improve the control of such governments and institutions over their own educational 
DOE's presence "shall not increase the authority of the Federal Government over education or diminish the responsibility for education which is reserved to the States and the local school systems." ${ }^{24}$ To maintain the State's responsibility for education, the law forbids the DOE to "exercise any direction, supervision, or control over the curriculum, program of instruction, administration, or personnel of any educational institution, school, or school system." 125

Further, the federal commitment to State control over education periodically reappears in the United States Supreme Court, which recognizes "that local autonomy of school districts is a vital national tradition [citation omitted] and that a district court must strive to restore state and local authorities to the control of a school system operating in compliance with the Constitution." 126

For our purposes, the debate focuses on the merits of systemic features that exist in centralized and decentralized education systems. Generally speaking, a centralized education system means there is one central administrative authority that "has complete power over all the resources . . . It decides the content of curriculum, controls the budget, is responsible for employment, the building of educational facilities, discipline policies, etc." ${ }^{27}$

Federal law prohibits the United States from having a centralized education system. ${ }^{128}$ Instead, under the current U.S. system, "decisions about standards are made at the state level . . . Curriculum decisions, including which textbook and programs to use, are made by local districts. Instructional decisions regarding student progress throughout the year are made in the classroom." 129

programs and policies. The establishment of the Department of Education shall not increase the authority of the Federal Government over education or diminish the responsibility for education which is reserved to the States and the local school systems and other instrumentalities of the States.

(b) Curriculum, administration, and personnel; library resources.

No provision of a program administered by the Secretary or by any other officer of the Department shall be construed to authorize the Secretary or any such officer to exercise any direction, supervision, or control over the curriculum, program of instruction, administration, or personnel of any educational institution, school, or school system, over any accrediting agency or association, or over the selection or content of library resources, textbooks, or other instructional materials by any educational institution or school system, except to the extent authorized by law.”)

${ }^{124} I d$.

$125 \mathrm{Id}$.

${ }^{126}$ Mo. v. Jenkins, 515 U.S. 70, 99 (1995) (citing Dayton I, 433 U.S. at 410; Freeman, 503 U.S. at 489; Dowell, 498 U.S. at 247).

${ }^{127}$ Annick M. Brennen, Centralization Versus Decentralization, http://www. soencouragement.org/centralizationvsdecentralization.htm (last visited Oct. 20, 2013) (arguing for the decentralization of The Bahamas' education system).

12820 U.S.C.A., supra note 123.

${ }^{129}$ Campbell, supra note 121. 


\section{Federal Law vs. State Autonomy}

The antagonistic theme opposing CCSS is a consequential federal overhaul of education. ${ }^{130}$ The topic has spurred national debate since the late $1800 \mathrm{~s},{ }^{131}$ but "national education standards have not been the property of one political party." "132 Both Democrats and Republicans have taken turns being champions of standards-based reform at the federal level. ${ }^{133}$

\section{Determining What to Teach}

Critics state that CCSS represents an encroachment on state autonomy and establishes the basis for a centralized education system. ${ }^{134}$ Education historian Diane Ravitch stated that she believes in voluntary national standards, but "not those imposed by the federal government." 135 However, since decisions concerning standards are made at the state level, individual states had to choose whether to adopt CCSS. ${ }^{136}$ Similarly, states had to choose whether to adopt the common assessment aligned to CCSS. ${ }^{137}$ Proof of this lies in the fact that five states initially rejected CCSS. ${ }^{138}$ Further, three CCSS adoptive states have since passed legislation to replace CCSS. ${ }^{139}$ Georgia provided another example of state autonomy by electing to adopt CCSS, but not implement one of the accompanying assessments. ${ }^{140}$

Adoption of CCSS is defined as accepting that the standards "will account for 85 percent of the total number of the standards in a subject area, meaning states have the option to identify as much as 15 percent in

${ }^{130}$ Kohn, supra note 14.

131 SuPERFINE, supra note 12.

132 Melanie Rhoads, Ron Sieber \& Susan Slayton, Examining National Standards 2 (1996), http://horizon.unc.edu/projects/issues/index.html (last visited Feb. 5, 2014).

133 See Boyce Brown, Standards-Based Education Reform in the United Stated Since "A Nation at Risk” (2009).

${ }^{134}$ Kohn, supra note 14; C.f. Kathleen Porter-Magee, A Testimony on the Common Core Standards, Thomas B. Fordham Institute (May 22, 2013), http://www.edexcellence. net/commentary/education-gadfly-daily/common-core-watch/2013/a-testimony-on-thecommon-core-standards.html (arguing that adoption of CCSS at the state level ensures local control of curricular decision).

135 Strauss, supra note 77.

${ }^{136}$ RT3 Scoring Rubric, supra note 8, at 7.

${ }^{137}$ Id.

${ }^{138}$ Washington, supra note 120.

139 Valerie Strauss, Two More States Pull Out Of Common Core, WAsh. Post., http://www.washingtonpost.com/blogs/answer-sheet/wp/2014/06/05/two-more-statespull-out-of-common-core/ (Jun. 5, 2014). It should be noted that Indiana, the first of the adoptive CCSS state to replace CCSS, has faced criticism of its newly adopted standards as "rebranded" CCSS. Summer Ballentine, Indiana Approves Common Core Replacement Standards, Huff Post, http://www.huffingtonpost.com/2014/04/28/indianacommon-core-replacement_n_5228212.html (Apr. 28, 2014, 3:46 PM).

${ }^{140} I d$. 
additional standards once they've accepted the Common Core verbatim.”141 This is referred to as the "fifteen percent rule," and allows each state to "add an additional 15 percent on top of the core." ${ }^{142}$ For example, writing in cursive is not part of the CCSS, ${ }^{143}$ but the fifteen percent rule enables any state to add cursive writing to their state standards. This permitted both Alabama and California to adopt CCSS, but include cursive as a part of their state standard. ${ }^{144}$ The fifteen percent rule acknowledges that there is core conceptual knowledge that all students need to be college and career ready as evidenced by all the states adopting CCSS as at least eighty-five percent of their standards.

Critics claim that "students have unique backgrounds that only state and local governments can take into account when creating standards and tests." 145 In the United States, considering the widespread access to resources through the Internet and media, an argument cannot survive that holds there are not enough core universal concepts that apply to all children. ${ }^{146}$ Regardless of how unique of a background a student because of her situation or state, "[t]wo plus two equals four whether a child lives in California, Iowa, or New York." 147

Acknowledging that outside of this core conceptual knowledge, emphasis on certain content knowledge can vary between states, the fifteen percent rule makes tailoring the CCSS to state needs permissible. The efficaciousness of the rule is shown by the eleven CCSS states adding "state-specific standards in at least one subject, while several states added explanatory or supporting material to their state versions of Common Core documents." ${ }^{148}$ California is a front-runner in utilizing of the fifteen percent rule, as the state "added 17 standards and appended 26 detailed statements" to math and added " 36 new statements and 33 added details to standards and statements" in language arts. ${ }^{149}$

141 John Kendall et al., State Adoption of the Common Core State Standards: the 15 Percent Rule, 1 (2012), available at http://www.mcrel.org/ /media/Files/McREL/

Homepage/Products/01_99/prod17_15PercentRule.ashx.

${ }^{142} I d$. at 2.

143 See generally Common Core State Standards Initiative, English Language Arts Standards, Writing, http://www.corestandards.org/ELA-Literacy/W/introduction/ (last visited Jan. 11, 2014). (Ability to write in cursive is not a standard.)

144 John Kendall et al., supra note 141, at 56.

145 Thomas F. Risberg, National Standards and Tests: The Worst Solution to America's Educational Problems ... Except for All the Others, 79 Geo. WASH. L. REV. 890, 911 (2011). E.g., Letter from Rick Perry, Governor of Tex., to Arne Duncan, U.S. SEC'Y OF Educ. (Jan. 13, 2010), available at http://governor.state.tx.us/files/press-office/ODuncanArne201001130344.pdf.

${ }^{146} \mathrm{Id}$. at 911.

${ }^{147}$ MCCluskey, supra note 1 , at 2.

148 John Kendall et al., supra note 141, at 1.

${ }^{149} \mathrm{Id}$. at 8. 
Additionally, CCSS adoption only represents mathematics and English-language arts standards (ELA). ${ }^{150}$ Math and ELA standards were specifically developed "because they are areas upon which students build skill sets which are used in other subjects." "151 This means states retain full control over all other content areas like science, social studies, music, art, etc., subjects which naturally lend themselves to more variable interpretation of what needs to be taught and learned. ${ }^{152}$ An example of this occurred in Colorado, where officials created a "hybrid between the Common Core and a set of its own new aggressive standards in 10 disciplines-including dance and music.”153

The DOEOA prohibits the federal government from exercising "any direction, supervision, or control over the curriculum, program of instruction." 154 This means the federal government is prohibited from mandating nationalized standards or a national curriculum. ${ }^{155}$ If CCSS were federally mandated, it would be a violation of federal law. ${ }^{156}$ However, CCSS is state led and participation is voluntary. ${ }^{157}$

Despite the voluntary nature of CCSS, critics contend that RT3's contingent funding coerced states into adopting CCSS, thereby violating Tenth Amendment of the Constitution. ${ }^{158}$ However, advocates counter with Supreme Court jurisprudence like South Dakota v. Dole, ${ }^{159}$ which permits the government to "place reasonable conditions on money to the states through Congress' spending powers." ${ }^{\prime 160}$ Dole placed limits on conditional

\footnotetext{
${ }^{150}$ See generally Common Core State Standards Initiative, Frequently Asked Questions, http://www.corestandards.org/resources/frequently-asked-questions (last visited Oct. 20, 2013).

${ }^{151}$ Id.

$152 \mathrm{Id}$.

${ }^{153}$ State by State: How 8 Key States Are Handling The Common Core, The HeChinger REPORT, http://hechingerreport.org/content/state-by-state-how-8-key-states-arehandling-common-core_13327/

15420 U.S.C.A. § 3403 (West 1979), supra note 123.

${ }^{155} \mathrm{Id}$.

156 See Sandy Kress, Stephanie Zechmann \& J. Matthew Schmitten, Symposium,Education Reform: When Performance Matters: The Past, Present, and Future Of Consequential Accountability In Public Education, 48 HARV. J. ON LEGIS. 185, 220.

${ }^{157}$ Id.

${ }^{158}$ Risberg, supra note 145, at 910 (citing Daryl Luna, National Standards Will Merely Produce National Dominance, Tenth Amendment CtR. (Mar. 14, 2010), http://tenthamendmentcenter.com/2010/03/14/national-standards-will-merely-producenational-dominance/\#.UuapfXn0CfQ.

159 S. Dakota v. Dole, 483 U.S. 203, 206 (1987).

160 Risberg, supra 145, at 910; See generally Allison Quick, Legal Limits on Conditional Spending including Recent Challenges To No Child Left Behind, Briefing Paper No. 19 (2006), available at http://www.law.harvard.edu/faculty/hjackson/No Child_19.pdf.
} 
funding under the spending clause by delineating those financial inducements that "pass the point at which pressure turns into coercion."161

While the provisions of RT3 were deliberately incentivizing state education reform, the voluntary adoption of CCSS only represented eight percent or forty of the possible five hundred total RT3 application points. ${ }^{162}$ Further, the voluntary adoption of the assessment aligned to CCSS represented thirty points. ${ }^{163}$ Because both CCSS and the accompanying assessment represent fourteen percent of the total RT3 application, ${ }^{164}$ and the fact that several states chose not to adopt CCSS or the assessment, ${ }^{165}$ it is evident that the conditional federal funding does not "pass the point at which pressure turns into coercion." ${ }^{166}$ Finally, conditional federal funding based on education reform has become commonplace in education policy with both the Democratic and Republican parties. ${ }^{167}$

\section{Determining How to Teach}

An extension of the Tenth Amendment argument is that CCSS is the basis for a national curriculum and assessment. ${ }^{168}$ The argument is that because all curricula is aligned to standards, and since RT3 funding is contingent on adopting CCSS, the DOE is indirectly controlling a national curriculum in violation of the law. ${ }^{169}$ There is validity in saying standards guide curriculum, ${ }^{170}$ but the federal government does not control CCSS. CCSS is a "state-led effort" that includes "governors and state commissioners of education from 48 states, two territories and the District

\footnotetext{
${ }^{161}$ Our decisions have recognized that in some circumstances the financial inducement offered by Congress might be so coercive as to pass the point at which "pressure turns into compulsion.” S. Dakota v. Dole, 483 U.S. 203, 211 (1987) (internal quotations removed) (quoting Steward Machine Co. v. Davis, 301 U.S. 548 (1937)).

162 RT3 Scoring Rubric, supra note 8, at 7.

${ }^{163} \mathrm{Id}$.

${ }^{164}$ Id.

165 Washington, supra note 120.

166 "Our decisions have recognized that in some circumstances the financial inducement offered by Congress might be so coercive as to pass the point at which "pressure turns into compulsion.” S. Dakota v. Dole, 483 U.S. at 211 (internal quotations removed) (quoting Steward Machine Co. v. Davis, 301 U.S. 548 (1937)).

167 IASA, supra note 91 (under President Clinton); NCLB, supra note 100 (under President George W. Bush); See also Risberg, supra 144, at 910. NCLB "already condition[ed] education funding on states creating their own standards and tests."

168 Jonathan Butcher, et al., Why the Common Core is Bad for America, WAsH. PoL'y. CENTER (May 2012), http://www.washingtonpolicy.org/publications/notes/whycommon-core-bad-america.

${ }^{169} \mathrm{Id}$.

${ }^{170}$ Campbell, supra note 121.
} 
of Columbia.” ${ }^{171}$ The collaborators, all members of the National Governors Association Center for Best Practices (NGA Center) and Council of Chief State School Officers (CCSSO), "received nearly 10,000 comments" during the public comment period "from teachers, parents, school administrators and other citizens" that helped shape the standards. ${ }^{172}$ Thus, the assertion that only a "relatively small group of experts will be designing standards . . - based on their personal assumptions about what it means to be well educated," ${ }^{173}$ is unfounded.

CCSS does not set forth the expectation that every student in the country must learn the exact same way. States adopting CCSS retain full control over determining the best way to meet those standards. For example, CCSS states agree that a second grader needs to be able to "[a]sk and answer such questions as who, what, where, when, why, and how to demonstrate understanding of key details in a text." 174 This does not mean CCSS states agree what books will be read or how much time needs to be spent teaching the necessary skills for mastery. That is the job of school boards, districts, and teachers. ${ }^{175}$ The standard represents that regardless of what state, everyone agrees that a successful second grader needs to have that skill.

\section{Determining How to Test}

As previously stated, RT3 incentivized the adoption of CCSS and an accompanying assessment aligned to those standards. ${ }^{176}$ While some opponents assert the dangers of "teaching to the test" and a single national exam, proponents counter by stating a multitude of national tests already

\footnotetext{
${ }^{171}$ Common Core State Standards Initiative, About The Standards - Development Process, http://www.corestandards.org/resources/process (last visited Jan. 27, 2014).

${ }^{172}$ Id. See also Janelle L. Rivers, League of Women Voters, Common Core Standards and Assessments 3 (2011), available at http://www.beachcities.ca.lwvnet.org/files/ commoncorestandards-background.pdf (The developers collaborated with teachers, school administrators and experts, and then took into account over 10,000 public comments in order to develop standards.); C.f. Strauss, supra note 77. Diane Ravitch still asserts "there was minimal public engagement in the development of [CCSS].”[Id.?]

${ }^{173}$ Kohn, supra note 14. Further, the CCSS website states that "The National Education Association (NEA), American Federation of Teachers (AFT), National Council of Teachers of Mathematics (NCTM), and National Council of Teachers of English (NCTE), among other organizations were instrumental in bringing together teachers to provide specific, constructive feedback on the standards." Common Core State Standards Initiative, Frequently Asked Questions, supra note 150.

174 Common Core State Standards Initiative, English Language Arts Standards, Reading: Literature, Grade 2, CCSS.ELA-Literacy.RL.2.1, http://www.corestandards. org/ELA-Literacy/RL/2 (last visited Jan. 11, 2014) (emphasis added).

17520 U.S.C.A. § 3403 (West 1979), supra note 123.

${ }^{176}$ RT3 Scoring Rubric, supra note 8, at 7.
} 
exist and reiterate that the assessment is voluntary. ${ }^{177}$ In 2010, two state consortiums were awarded RT3 funding to assist in creating assessments. ${ }^{178}$ CCSS states are split nearly in half between two computer-based assessments: the Smarter Balanced Testing Consortium (SBTC) ${ }^{179}$ and the Partnership for Assessment of Readiness for College and Careers (PARCC). ${ }^{180}$ For the 2014 -2015 year, states have the option to assess using SBTC, PARCC, or continue using their current assessment models. ${ }^{181}$ Proponents tout SBTC's “computer adaptive testing” 182 that adjusts to the student's ability during the exam, and the focus on "more authentic measures of student learning" that provide teachers with "actionable information to improve performance." ${ }^{183}$ Both computer-based tests provide real time feedback for students, and a breakdown of student deficiencies for educators and parents to provide targeted instruction. ${ }^{184}$

Opponents argue implementing CCSS will be cost prohibitive. ${ }^{185}$ Though costs will vary state-to-state, ${ }^{186}$ the Association for

177 Butcher, supra note 168; The National Center for Fair and Open Testing, Common Core Assessment Myths and Realities: Moratorium Needed From More Tests, Costs, Stress FAIRTEST (Sept. 3, 2013, 11:55AM), http://www.fairtest.org/common-coreassessments-factsheet; C.f. Porter-Magee, supra note 134.

178 Robert Rothman, Something in Common, The Common Core Standards and the NeXt Chapter in American Education 148 (2011); U.S. Dep’t of Educ., Race to the Top Assessment Program, http://www2.ed.gov/programs/racetothetopassessment/applicant.html (last visited Feb. 5, 2014).

179 Rothman, supra note 178, at 149; See generally Smarter Balanced Testing Consortium, Frequently Asked Questions, http://www.smarterbalanced.org/resourcesevents/faqs/ (last visited Feb. 5, 2014).

180 Rothman, supra note 178, at 149. See generally Partnership for Assessment of Readiness for College and Careers, PARCC Frequently Asked Questions, http://www.parcconline.org/sites/parcc/files/PARCCFactSheetandFAQsBackgrounder_ FINAL.pdf (updated Sept. 2013).

181 The Aspen Institute, Publications, The Common Core State Standards: An Introduction for Families and Other Stakeholders (April 19, 2013), http://www.

aspeninstitute.org/publications/common-core-state-standards-introduction-familiesother-stakeholders (last visited Feb. 5, 2014); E.g., Letter from Rick Perry, Governor of Tex., to Arne Duncan, U.S. Sec’y of Educ., supra note 145.

182 “Computer adaptive testing adjusts to a student's ability by basing the difficulty of future questions on previous answers, providing more accurate measurement of student achievement, particularly for high and low-performing students.” Smarter Balanced Testing Consortium, Frequently Asked Questions, http://www.smarterbalanced.org/ resources-events/faqs/ (last visited Feb. 5, 2014).

183 The Aspen Institute, supra note 181.

184 Partnership for Assessment of Readiness for College and Careers, PARCC Frequently Asked Questions, http://www.parcconline.org/sites/parcc/files/PARCCFact SheetandFAQsBackgrounder_FINAL.pdf (updated Sept. 2013).

185 E.g., The National Center for Fair and Open Testing, Common Core Assessment Myths and Realities: Moratorium Needed From More Tests, Costs, Stress FAIRTEST (Sept. 3, 2013, 11:55AM), http://www.fairtest.org/common-core-assessments-factsheet; 
Supervision and Curriculum Development (ASCD) reports that "about half of the PARCC states currently spend more on their summative tests" and SBTC will cost "less than what two-thirds of its member states currently pay for their assessments.” ${ }^{187}$ Despite the potential realities of increased costs, proponents argue that because the average school district currently spends more than ten thousand dollars per pupil on education, an additional ten or twenty dollars per student represents a worthwhile investment. ${ }^{188}$

ASCD concedes that other associated costs like upgrading technological infrastructure will have a greater impact on some states. ${ }^{189}$ Despite the new standards initially costing states more money, ASCD states that the cost will be discounted by the long-term benefits of sharing resources for testing and educator professional development. ${ }^{190}$

The Thomas B. Fordham Institute describes three possible implementation scenarios that translate roughly to full ("business as usual"), minimum ("bare-bones"), and balanced implementation. ${ }^{191}$ The Institute estimates that "it is possible for a state to cover most [if not all] of its transitional via existing expenditures" using the "bare bones” approach, "as much as three-fourths" using the "balanced implementation," and "about one-third" of the full or "business as usual” approach. ${ }^{192}$ Irrespective of which model each state implements, "textbooks, study materials, and technological upgrades must be funded" regardless, even in the absence of CCSS. ${ }^{193}$

Finally, the two perennial college admission exams, the ACT and

Perry Chiaramonte, High cost of Common Core has states rethinking the national education standards, FoxNews, (Feb. 5, 2014), http://www.foxnews.com/us/2014/02/

05/number-states-backing-out-common-core-testing-maryland-schools-low-on-funding/.

${ }^{186}$ E.g., STAND for Children, Common Core State Standards Myth vs. Fact 2 http://stand.org/indiana/common-core/myths-vs-facts. (In Indiana "because the state allowed districts to make technology investments with textbook funds starting in 2009 . This means most - if not all - of [CCSS] implementation costs can be covered by existing spending.”).

${ }^{187}$ Association for Supervision and Curriculum Development, Policy Points 3 (2012), available at http://www.ascd.org/ASCD/pdf/siteASCD/publications/policypoints/Policy Points_Common_Core_State_Standards.pdf [herinafter ASCD].

188 Rothman, supra note 178, at 161.

189 ASCD, supra note 187.

190 Id. Ssee also Briefing Packet: Common Core State Standards, JAmes B HunT, JR INSTITUTE FOR EDUCATIONAL LEADERSHIP AND POLICY, http://www2.ed.gov/programs/ racetothetop/communities/hunt-institute-briefing-packet.pdf (last visited Nov. 2, 2014) ("[C]onsistent English Language Arts and Mathematics Standards shared by states offer an unprecedented opportunity to pool expertise and resources.”).

191 Patrick Murphy et al., Putting a Price Tag on the Common Core: How Much Will Smart Implementation Cost? Thomas B Fordham Institute 2 (May 2012), http:// edexcellence.net/sites/default/files/publication/pdfs/20120530-Putting-a-Price-Tag-onthe-Common-Core-FINAL_7.pdf.

192 Id. at 6.

193 Chiaramonte, supra note 185. 
SAT, are both aligned to CCSS. ${ }^{194}$ This means "college-and careerready" ${ }^{\prime 95}$ is the same standard for every high school student in the country. Additionally, “college-and career-ready" ${ }^{196}$ means CCSS.

\section{Why Implement CCSS}

As the preceding sections on standards-based reform demonstrate, the central arguments for and against nationalized standards have remained static, only varying slightly with each reincarnation's new attempt at implementation. ${ }^{197}$ For example, the same arguments today can be traced to 1993, when the DOE commissioned a report analyzing the "criteria and processes” of NESIC (President Clinton's federal review board that analyzed state standards), ${ }^{198}$ to be presented to the National Education Goals Panel. ${ }^{199}$ The report synthesized the need for national education standards into three central points: [1] to promote educational equity; [2] to preserve democracy and improve economic competitiveness; and [3] to provide "an increasingly diverse and mobile population with shared values and knowledge." ${ }^{200}$ The report emphasized the ability of nationalized standards to: provide student, parent, and teacher transparency on levels of achievement expected; progress monitoring of student performance and accountability for that performance; assist policymakers with programmatic decisions; and finally, improve educational outcomes for all students. ${ }^{201}$ Similarly, today's advocates cite a more clear set of classroom and testing expectations for students, parents, and teachers; a basis for comparing student achievement; and a "marketplace" for sharing innovative curricular materials. ${ }^{202}$ Finally, proponents state that CCSS can limit the "adverse effects of student mobility." 203

\footnotetext{
194 Valerie Strauss, SAT Exam to be Redesigned, WASH. Post (Feb. 26, 2013, 4:56PM), http://www.washingtonpost.com/blogs/answer-sheet/wp/2013/02/26/sat-exam-to-beredesigned/;

Common Core State Standards, ACT, http://www.act.org/solutions/college-careerreadiness/common-core-state-standards/ (last visited Feb. 5, 2014).

195 White House, supra note 6.

${ }^{196} I d$.

197 See Brown, supra note 133.

198 Goals 2000, supra note 89, § 211. C.f., Ava Arsaga, What are the Common Core State Standards? PARENT CoRTICAL MAss (Mar. 27, 2012), http://www.

parentcorticalmass.com/2012/03/what-are-the-common-core-state-standards-1.html.

199 Emily Wurtz et al., Promises to Keep: Creating High Standards fOr American STUDENTS 56 (1993), available at http://govinfo.library.unt.edu/negp/reports/promises .pdf (report by the Technical Planning Group to the National Education Goals Panel).

${ }^{200}$ Id.

${ }^{201}$ Id. at 58.

202 Arsaga, supra note 198.

${ }^{203}$ Id. See also Chad Aldis, Standards help students forced to move often, NEWARK AdvocATE (Feb. 12, 2014), http://www.newarkadvocate.com/article/20140212/
} 
Critics, such as Diane Ravitch, claim CCSS “will cause a precipitous decline in test scores" and have a "disparate impact on students who are English language learners, students with disabilities, and students who are poor and low-performing." 204 Similarly, critics claim nationalized standards "will only validate, rather than help eliminate, vast inequalities in educational outcomes and economic opportunity." 205 As a consequence, if the learning expectations were defined and transparent, but then society "denies some students the opportunity to acquire them," it imposes penalties against low-scoring students and reinforces "the inequality and provides a basis for further unequal treatment." 206

Advocates support the assertion that "test scores will initially go down," but that only "a level playing field ensures that all students will face the same challenges." 207 It is only through this level playing field that an education system can identify "the inequities among schools, which could be considered the first step towards redressing them.”"208

In 2012, Harvard University's Program on Education Policy and Governance \& Education Next released a report examining international and domestic achievement growth trends. ${ }^{209}$ The study found that "[s]tates with the largest gains in average student performance also tend to see the greatest reduction in the percentage of students performing below the basic level." 210 Those same states also had "the largest percent shift of nonproficient” to proficient students on NAEP. ${ }^{211}$ This represented an "educational tide," which lifted all students. ${ }^{212}$ Ultimately, a focus on equity increased the amount of proficient students, which in turn, lifted entire state averages.

The 1993 DOE report's summative message stated, “[i]n the absence of well-defined and demanding standards, education in the United States has gravitated toward de facto national minimum expectations." ${ }^{213}$

OPINION02/302120043/Standards-help-students-forced-move-often ("With tens of thousands of students moving in and out of Ohio schools each year, our teachers, students and families are left putting puzzle pieces together to ensure students learn what is needed. One student who may be advanced in one school could move to another school where she falls short of its classroom standard. This problem and other similar issues pose a dilemma for mobile students.”).

204 Strauss, supra note 77.

205 Jay P. Heubert, LAW and School Reform: Six Strategies for Promoting EduCATION Equity 31 (Jay P. Heubert ed., 1999).

${ }^{206} I d$.

207 The Common Core State Standards, supra note 181.

208 ORg. FOR ECON. CO-OPERATION AND DEV. IV, PISA 2009 RESUlts: What MAKES A School Successful? Resources, Policies AND Practices 47 (2010) [hereinafter OECD, What Makes a School Successful?].

${ }^{209}$ HANUSHEK ET AL., supra note 21.

${ }^{210}$ Id.at vii.

${ }^{211}$ Id.

${ }^{212} \mathrm{Id}$.

${ }^{213}$ WURTZ ET. AL, supra note 199, at 55. 
Regardless of race or gender, "there is a certain set of educational skills one must have to be successful in academia or business." ${ }^{214}$ CCSS represents each participating state's acknowledgement of a core set of skills that all students need. Further, CCSS does not infringe on state autonomy because the pedagogical decisions for achieving those core concepts still belongs to the states. ${ }^{215}$

\section{INTERNATIONAL LEGAL SYSTEMS AND NATIONALIZED STANDARDS}

According to the OECD, many countries "reproduce existing patterns of socio-economic advantage," meaning socioeconomically disadvantaged students are deprived social mobility because of the inequitable distribution of learning opportunities. ${ }^{216}$ Despite the cyclical nature and byproducts of educational inequity, the 2012 PISA results "demonstrate[d] that high average performance and equity are not mutually exclusive.”217 In 2009 and 2012, OECD identified South Korea, Finland, and Canada as countries that combined "above-OECD-average performance" while maintaining "a weak relationship between socio-economic status and student performance." 218 Not surprisingly, OECD acknowledged that a country's policies and practices directly impact "both equity and performance." 219

OECD's identification process examined each country's overall mean averages in mathematics and reading and the "percentage of explained variance" in those subjects based on the variability in distribution of students on the PISA index of economic, social, and cultural status (ESCS). ${ }^{220}$ The identification is not just whether the country scored high, but whether while scoring high, the country distributed ESCS rankings

\footnotetext{
${ }^{214}$ Risberg, supra note 145 , at 924.

215 Arne Duncan, U.S. Sec'y of Educ, Address by the Secretary of Education at the 2009 Governors Education Symposium 5 (Jun. 14, 2009) ("Federal law does not mandate national standards. It empowers states to decide what kids need to learn and how to measure it. But common sense also tells you that kids in big cities like Newark and San Francisco, or small towns like Tarboro, North Carolina, are no different from each other. Standards shouldn't change once you cross the Mississippi River or the Rocky Mountains. Kids competing for the same jobs should meet the same standards.”).

216 ORg. FOR ECON. Co-OPERATION AND DEV., PISA 2012 RESUltS IN FocUs - WhAt 15YEAR-OLDS KNOW AND WHAT THEY CAN DO WITH WHAT THEY KNOW 13 (2013), available at http://www.oecd.org/pisa/keyfindings/pisa-2012-results-volume-i.htm [hereinafter OECD, RESULTS IN FOCUS].

${ }^{217} \mathrm{Id}$. at 14.

${ }^{218}$ Id.; ORg. FOR ECON. CO-OPERATION AND DEV. II, PISA 2009 RESUlts: Overcoming Social BACKGROUND: Equity IN LEARNing OpPoRTunities AND OUTCOMES 101 (2010) [hereinafter OECD, EQUITY IN LEARNING OPPORTUNITIES].

${ }^{219}$ OECD, REsults IN Focus, supra note 216, at 13.

${ }^{220}$ ESCS Variance, supra note 40.
} 
evenly, rather than concentrated in the lower half of scoring students. As Table 1 demonstrates, all four selected countries score higher than the United States in math and reading while lessening the impact of student's socioeconomic status.

Table $1 .^{221}$

\begin{tabular}{|c|c|c|c|c|}
\hline & $\begin{array}{c}\text { Mean } \\
\text { Score in } \\
\text { Mathematics }\end{array}$ & $\begin{array}{r}\text { Percentag } \\
\text { e of Explained } \\
\text { ESCS Variance } \\
\text { in Mathematics }\end{array}$ & $\begin{array}{c}\text { Mean } \\
\text { Score } \\
\text { Reading }\end{array}$ & $\begin{array}{r}\text { Percentag } \\
\text { in }\end{array}$ \\
$\begin{array}{c}\text { ef Explained } \\
\text { ESCS Variance } \\
\text { in Reading }\end{array}$ \\
\hline $\begin{array}{c}\text { OECD } \\
\text { Average }\end{array}$ & 494 & 14.8 & 498 & 13.1 \\
\hline $\begin{array}{c}\text { United } \\
\text { States }\end{array}$ & 481 & 14.8 & 498 & 12.6 \\
Canada & 518 & 9.4 & 523 & 8.1 \\
Finland & 519 & 9.4 & 524 & 7.5 \\
Japan & 536 & 9.8 & 538 & 7.9 \\
Korea & 554 & 10.1 & 536 & 7.9 \\
\hline
\end{tabular}

In light of information, this section reviews the law, policies, and practices of Japan, Finland, South Korea, and Canada, four of the countries continually identified as scoring above the OECD average while minimizing the impact of socioeconomic status. ${ }^{222}$

\section{A. Japan}

In 2006, Japan revised its Basic Act on Education for the first time in

221 Education GPS, ORG. FOR ECON. CO-OPERATION AND DEV., http://gpseducation.oecd.org/Home (last visited Feb. 5, 2014) (the OECD website allows users to generate data reports by selecting countries and the specific measures wishing to be viewed) [hereinafter OECD, Data Report Generator]. See also OECD, Excellence through Equity, supra note 35, at 15, TABLE II.A (2013). It should be noted that in OECD's Table II.A, Hong Kong-China and Macao-China appear to represent the highest scores in mean average and equity. However, China's data has been objected to for alleged selective reporting procedures, meaning the country's statistics only represent selected areas rather than the entire country. See David Stout, China is Cheating the World Student Rankings System, Time (Dec. 4, 2013), http://world.time.com/2013/12/04/china-is-cheating-the-world-student-rankingssystem/. As such, this Note does not focus on China.

222 OECD, Data Report Generator, supra note 221. 
almost sixty years. ${ }^{223}$ Under the previous system, the principles of Japanese education were "defined in the Constitution of Japan enacted in 1946 and the Fundamental Law of Education enacted in 1947." 224 From World War II until 1992, Japan represented the quintessential centralized structure of education governance with a test-based system guided by a national curriculum overseen by a federal body. ${ }^{225}$ Critics asserted that the uniform focus "on developing rote knowledge and scoring well on tests" proved detrimental to "individuality and creativity." 226 The "uniformity and rigidness" of this resulted in curricular revisions implemented in 1992 and $2002 .{ }^{227}$ The curricular shift not only shortened the school week from six to five days, it also gave "teachers considerable freedom by laying down only brief and general guidelines about content and teaching." 228

Still unsatisfied, the Ministry of Education, Culture, Sports, Science, and Technology (MEXT) issued a national report in 2004, calling for reforms to the Fundamental Law of Education. ${ }^{229}$ MEXT cited four reasons for reform:

[1] The "great fall in educational functions in the home and in the community against the backdrop of urbanization;" [2] The "deterioration in social skills, sense of importance of keeping rules, and moral consciousness among young people;" [3] The "uniformed education system that overstresses egalitarianism and cramming of too much knowledge" diminishes focus on "each individual child's personality and ability;" [4] and the current system did not sufficiently respond to "the progress of society" and "rapid changes" in science, technology and economic globalization. ${ }^{230}$

In 2006, the Japanese education reform movement culminated with

223 Basic Plan for the Promotion of Education - Introduction, Ministry OF EdUC., Culture, Sports, SCI. \& TECH. (provisional translation), http://www.mext.go.jp/ english/lawandplan/1303463.htm [hereinafter MEXT Basic Plan].

224 The Development of Education in Japan, Ministry of EduC., Culture, Sports, Sci. \& TECH. (2004), http:// www.ibe.unesco.org/International/ICE47/English/Natreps/ reports/japan.pdf [hereinafter MEXT Development of Education].

225 See generally id.

226 See Joseph Strong, Note, "The Grass is Always Greener": A Look at Educational Reform in the United States and Japan, 21 Transnat'L L. \& Contemp. Probs. 277, 285 (2012).

227 Id. at 284-85.

${ }^{228} \mathrm{Id}$. at 285.

${ }^{229}$ MEXT Development of Education, supra note 224, at 58.

${ }^{230}$ Id. See also Strong, supra note 226, at 287. 
passage of the Basic Act on Education. ${ }^{231}$ The Act, in conjunction with the 1992 and 2002 curricular revisions, embodied the "abandonment of the previous system predicated on the creation of a uniform body of knowledge for all students, to adopting a more relaxed approach based on individuality and creativity." 232 However, the new education structure still maintains components of the Fundamental Law on Education. ${ }^{233}$ The most relevant portions provide: an equal opportunity to receive education; ${ }^{234}$ that the national and local governments must cooperatively implement and "ensure adequate standards;" 235 that the national government shall formulate "education measures in order to provide for equal opportunities in education and to maintain and raise education standards throughout the country;" 236 that the national government shall create a plan of "basic principles" and "required measures" for the "comprehensive and systematic .. . promotion of education," ${ }^{237}$ while local governments implement the national plan "corresponding to regional circumstances." 238

In compliance with the Basic Act on Education, MEXT created the Basic Plan for the Promotion of Education in 2008. ${ }^{239}$ The Basic Plan called for a five-year comprehensive and systematic integration of: [1] horizontal cooperation, a "society-wide commitment to education" through community building and participation; [2] vertical connections, which creates "lifelong learning opportunities;" and [3] clarifying respective roles of the national and local governments. ${ }^{240}$ Under the third measure, the Basic Plan provides that the national government will establish "the framework of educational systems and standards of the Courses of Study to maintain or improve educational standards" and provide equal opportunity to that

${ }^{231}$ MEXT Basic Plan, supra note 223.

${ }^{232}$ Strong, supra note 226, at 277-78.

${ }^{233}$ Kyōiku Kenpō [Basic Act on Education], Law No. 120 of 2006 (Japan), translated at http://www.mext.go.jp/english/lawandplan/1303462.htm. C.f. MEXT Basic Plan, supra note 223.

${ }^{234}$ Kyōiku Kenpō [Basic Act on Education], Law No. 120 of 2006 (Japan), supra note 233, at art. 4, para. 1.

235 Id. at art. 5, ๆ. 3. Additionally, art. 16, para. 1 calls for cooperation, stating "education administration shall be carried out in a fair and proper manner through appropriate role sharing and cooperation between the national and local governments." Id. at art. 16,ף. 1.

${ }^{236} I d$. at art. 16, para. 2.

${ }^{237} I d$. at art. 17 , para. 1.

${ }^{238}$ Id. at art. 17, para. 2. Art. 16, para. 3 reiterates that the local governments shall "implement education measures corresponding to regional circumstances." Id. at art. 16, 9 3. It should also be noted that art. 18 further established the centralization of education as "[l]aws and regulations necessary to implement the provisions stipulated in this Act shall be enacted.” Id. at art. 18.

${ }^{239}$ MEXT Basic Plan, supra note 223.

${ }^{240} I d$. at ch. 3. 
framework. ${ }^{241}$ Conversely, the local government will meet "the needs and circumstances of respective regions," improve "the quality of their educational practices," control the related "administrative works," and "act autonomously to implement education, as such attitude is consistent with the decentralization policy." ${ }^{242}$ Finally, the national government concedes administrative control to the local governments as both entities work cooperatively to promote education. ${ }^{243}$

Education researcher Marc Tucker states that two central forces behind the quality and equity of Japanese education are "the quality of its teachers," 244 and that "all students are expected to master the same demanding curriculum." ${ }^{245}$ Further, Japan has quality control measures like the regular transfer of teachers and administrators between schools "every few years so the same people are not in the same schools all of the time." 246

\section{B. Finland}

In Finland, the Ministry of Education and Culture oversees public education and the "development of the national core curriculum through the Finnish National Board of Education." ${ }^{247}$ While appearing to be a categorically centralized system, the Finnish approach is somewhat atypical because of more recent characterizations of Finland having "one of the least prescriptive curricula."248

Finland's historical highlights include education legislation in 1966 and a national curriculum in 1970 designed to erase a fundamental belief that "everyone cannot learn everything" and that "talent is not evenly distributed in terms of one's ability to be educated." 249 Similar to Japan, Finland remained unsatisfied and promulgated the Nation Curriculum Reform of $1994,{ }^{250}$ which replaced "a previously rigid national curriculum

\footnotetext{
${ }^{241} I d$.

${ }^{242} I d$.

${ }^{243} I d$.

244 Tucker, supra note 12, at 92.

245 Id. at 95.

${ }^{246} I d$.

${ }^{247}$ Finland - System and School Organization, CENTER On INTERNATIONAL EDUCATION BENCHMARKING, http://www.ncee.org/programs-affiliates/center-on-internationaleducation-benchmarking/top-performing-countries/finland-overview/finland-systemand-school-organization/ (last visited Feb. 5, 2014).

248 MCKINSEY \& CO., HOW THE WORLD'S BEST-PERFORMING SCHOOL SYSTEMS COME OUT ON TOP 35 (2007), available at http://mckinseyonsociety.com/how-the-worlds-bestperforming-schools-come-out-on-top/ [hereinafter McKinsey \& Co., Best Performing Systems].

249 Pasi Sahlberg, FinNish Lessons, What CAN THE WORLD LEARN FROM EDUCATIONAL CHANGE IN FINLAND? 21 (2011).

${ }^{250} I d$. at 35.
} 
with targets for all students." 251 The result was a "much less detailed and prescriptive" curriculum. ${ }^{252}$ Further, the curriculum emphasizes teacher choice and adaptation "to the specific context in which they find themselves, and recognizes the fact that children learn at different rates, while at the same time setting high expectations for what should ultimately be achieved." ${ }^{253}$ Finally, unlike the United States, "Finland is culturally and ethnically rather homogenous."254

The central language in Finland's Basic Education Act calls for securing "adequate equity in education throughout the country." "255 The Act establishes that "[e]ducation shall be governed by a unified national core curriculum," ${ }^{256}$ and lists core subjects. ${ }^{257}$ The Act further provides that the national government "shall determine the general national objectives of education ... the allocation of lesson hours to the teaching of different subjects," and that the "National Board of Education shall determine the objectives and core contents of different subjects and cross-curricular themes." ${ }^{258}$ As part of the Ministry of Education, the Act created the Education Evaluation Council and authorizes the National Board of Education to monitor the evaluations. ${ }^{259}$

While the Act provides the structure for education, many researchers, including Pasi Sahlberg, state that the strongest feature of Finnish education is its teachers. ${ }^{260}$ Any teacher being certified must “obtain a master's degree as a condition of employment." 261 Further, the teaching profession's popularity means only the best students can enter certification programs, and only one in ten applicants are admitted to teacher education programs. ${ }^{262}$

Sahlberg also asserts that in Finland, equity in education "means more than just opening access to equal education for all;" it means a "high quality education for all in different places and circumstances." 263 Further,

\footnotetext{
${ }^{251}$ McKinsey \& Co., Best Performing Systems, supra note 248, at 35.

252 Tucker, supra note 12, at 62.

253 McKinsey \& Co., Best Performing Systems, supra note 248, at 35; see also Tucker, supra note 12 , at 62 .

${ }^{254}$ SAHLBERG, supra note 249 , at 8.

255 628/1998 Perusopetuslaki [Basic Education Act], § 2, para. 3 (Fin.), translated at http://www.minedu.fi/OPM/Koulutus/koulutuspolitiikka/lait_ja_ohjeet/?lang=en.

${ }^{256} I d$. § 3, para. 1.

${ }^{257} I$ Id. $\S 11$, para. 1. ("mother tongue and literature, the second national language, foreign languages, environmental studies, health education, religious education or ethics, history, social studies, mathematics, physics, chemistry, biology, geography, physical education, music, art, crafts, and home economics”).

258 Id. § 14.

259 Id. § 21.

260 See SAHLBERG, supra note 249, at 70.See also Tucker, supra note 12, at 51.

261 See Tucker, supra note 12, at 56.

262 See SAHLBERG, supra note 249 , at 73.

${ }^{263}$ Id. at 45.
} 
Sahlberg states that instead of "[s]etting clear, high, and centrally prescribed performance expectations for all schools, teachers, and students," that essentially standardizes "teaching and curriculum," the Finnish model sets a "clear but flexible national framework for school-based curriculum planning" that encourages "local and individual solutions to national goals." 264 Before the Curriculum Reform of 1994, "the ministry had two primary tools for regulating the quality of education: the national curriculum and the national school inspectorate.” ${ }^{265}$ Sahlberg argues that the word "accountability cannot be found in Finnish education" because Finland engages in "sample-based testing," not high stakes testing. ${ }^{266}$ While test sampling at the national level means students are not tested nationally every year, there is still "an enormous amount of diagnostic and formative assessment at the classroom level.,"267

\section{South Korea}

Korea similarly has a historically centralized education system. ${ }^{268}$ Korea's Elementary and Secondary Education Act provides that all public and private schools "shall be subject to the guidance and supervision" of the Minister of Education, Science and Technology (MEST) or the Superintendent of the Office of Education. ${ }^{269}$ Both MEST and the superintendent control "academic guidance on the operation of the educational curriculum and the methods of teaching and learning at school," including standards. ${ }^{270}$ As such, every five to ten years, MEST provides a new "national curriculum framework" containing subject content and "the amount of time to be spent on each subject per school year." ${ }^{271}$ Further, the act provides that MEST can evaluate academic of achievement of students and "local educational administrative agencies." 272

Additionally, Korea has three other relevant legislative acts. The Lifelong Education Act provides that "[a]ll citizens shall be guaranteed

\footnotetext{
${ }^{264} I d$. at 103.

265 Tucker, supra note 12, at 62.

${ }^{266}$ SAHLBERG, supra note 249, at 125.See also Tucker, supra note 12, at 62.

267 Tucker, supra note 12 , at 67.

268 South Korea - System and School Organization, CENTER ON INTERNATIONAL EDUCATION BENCHMARKING, http://www.ncee.org/programs-affiliates/center-oninternational-education-benchmarking/top-performing-countries/south-koreaoverview/south-korea-system-and-school-organization/ (last visited Feb. 5, 2014).

${ }^{269}$ Elementary and Secondary Education Act, Act No. 8917, art. 6, Mar. 21, 2008 (S. Kor.).

${ }^{270}$ Id. at art. 7.

271 Center on International Education Benchmarking, Top Performing Countries, South Korea, Instructional Systems, supra note 268.

${ }^{272}$ Elementary and Secondary Education Act, Act No. 8917, art. 9, 23, Mar. 21, 2008

(S. Kor.).
} 
equal opportunity for lifelong educations." ${ }^{273}$ The Local Education Autonomy Act provides for the establishment of local agencies "to utilize the independence and expertise of education and the particularity of local education." ${ }^{274}$ Finally, the Framework on Education Act provides that State and local governments "implement policies for minimizing gaps in educational conditions, such as supply and demand of teachers, among the regions to enable learners to gain access to equal opportunities in education." $^{275}$ The act also guarantees educational independence between State and local governments, allowing the execution of "educational policies reflecting actual situations of regions.”276 This means that while all schools follow the national curriculum framework, local "superintendents have the autonomy to add content and standards to address the needs of their schools." 277

Despite top ten scores in the 2000 PISA, researchers claimed Korea was unsatisfied and "concerned that only a narrow elite achieved levels of excellence in PISA." ${ }^{278}$ Focusing on quality and equity, Korea doubled its "share of students demonstrating excellence in reading literacy."279 This meant, "more than half of all disadvantaged students in Korea can be considered resilient.”280

The centralized Korean system of education often receives credit for an education turnaround, where "[s]ixty years ago, most South Koreans were illiterate; today, South Korean 15-year-olds rank No. 2 in the world in reading." "281 Challenging this rosy picture, others claim Korea has developed a high-pressure culture with "shadow school systems" that start after the normal school day ends. ${ }^{282}$ The result is nonstop schooling and a system "where private tutors now outnumber schoolteachers." 283 While the pressure created by the education culture is documented, ${ }^{284}$ Korea is still "characterised by a more socio-economically disadvantaged backgrounds"

273 Lifelong Education Act, Act No. 9641, art. 4, May 8, 2009 (S. Kor.).

${ }^{274}$ Local Education Autonomy Act, Act No. 8852, art. 1, Feb. 29, 2008 (S. Kor.).

275 Framework on Education Act, Act No. 8705, Art. 4, Dec. 21, 2007 (S. Kor.).

${ }^{276}$ Id. at Art. 5.

277 Center on International Education Benchmarking, Top Performing Countries, South Korea, Instructional Systems, supra note 268.

278 OECD, EQUITY In LEARNING OpPORTUNITIES, supra note 218, at 3.

${ }^{279} \mathrm{Id}$.

${ }^{280} I d$. at 62.

${ }^{281}$ Amanda Ripley, The \$4 Million Teacher, WALL ST. J. (Aug. 3, 2013, 4:46 AM).

${ }^{282} \mathrm{Id}$.

${ }^{283} \mathrm{Id}$.

${ }^{284}$ E.g., In Hypercompetitive South Koreas, Pressures Mount on Young Pupils, PBS (Jan. 21, 2011, 4:36 PM), http://www.pbs.org/newshour/bb/education-jan-june11koreaschools_01-21/; Reeta Chakrabarti, South Korea’s school: Long days, high results, BRITISH BROAD. CORP., http://www.bbc.co.uk/news/education-25187993 (last updated, Dec. 2, 2013). 
than the average OECD country, but scores above the OECD average in reading. ${ }^{285}$

\section{Canada}

Canada provides an alternative model to the centralized systems of Japan and Korea with a "limited to nonexistent federal role" in education. ${ }^{286}$ The Canadian Constitution guarantees provincial control, providing "[i]n and for each Province the Legislature may exclusively make Laws in relation to Education."287 This means that each of Canada's thirteen jurisdictions govern education individually ${ }^{288}$ through the guidance of their own "Minister of Education."289 In turn, each Minister of Education develops the curricula and standards for their respective jurisdiction. ${ }^{290}$

Similar to the U.S., authority over education is a historically local affair. ${ }^{291}$ Canada's only national presence is the Council of Ministers of Education (CMEC) ${ }^{292}$ CMEC is an intergovernmental body that promotes inter-province cooperation by providing "a forum to discuss policy issues”; a mechanism for undertaking projects of mutual interest; a means for facilitating cooperation with "national education organizations and the federal government"; and an instrument to represent Canadian education internationally. ${ }^{293}$ However, even the CMEC has been described as "limited in its impact because it acted only when all of the ministers agreed, which was infrequently." ${ }^{294}$ Ultimately, the CMEC leaves the administration of schools to the localities. ${ }^{295}$

Despite individual control, the provinces and territories show commonalities in their curricula. ${ }^{296}$ This is because the jurisdictions formed two consortia to determine curricular decisions: the Council of Atlantic Ministers of Education and Training and the Western Canadian Protocol (WCP) for Collaboration in Basic Education. ${ }^{297}$ The WCP produced groups of provinces cooperating to establish a common curricular guide for various

\footnotetext{
285 OECD, EQUITY IN LEARNING OpPORTUNITIES, supra note 218, at 33.

286 Tucker, supra note 12, at 141.

287 Constitution Act, 1867, c. 93 (Can.), available at http://laws-lois.justice.gc.ca/eng/ Const/index.html.

288 Tucker, supra note 12, at 141.

289 SCHMIDT ET AL., supra note 1.

${ }^{290} \mathrm{Id}$.

${ }^{291} \mathrm{Id}$.

292 See Council of Ministers of EduCation, What is CMEC?, http://www.cmec.ca /11/About/index.html (last visited Oct. 22, 2013).

${ }^{293}$ Id.

294 Tucker, supra note 12, at 146.

295 See SCHMIDT ET AL., supra note 1.

${ }^{296}$ Id.

${ }^{297} I d$.
} 
subjects, but recognized that implementation in each jurisdiction would look different and would need "to accommodate provincial or territorial needs." ${ }^{298}$ The result is that each province has a common curriculum, which ranges from very detailed, to basic guidelines, but is developed through "extensive consultation with groups of teachers and subject matter experts." ${ }^{299}$ Finally, the WCP curricular guide is described as "a floor, not a ceiling," for what will be taught in each classroom. ${ }^{300}$ This means the curricular guides establish a norm among the provinces for a baseline of achievement.

Canada has only recently garnished international attention for its educational progress. ${ }^{301}$ The recent attraction is not just about Canada's scores; it is about how their success shows "less dispersion among its high and low socioeconomic status students," despite being a "large, geographically dispersed, and culturally heterogeneous nation.” ${ }^{302}$ Further, "Canada has the highest rates of immigration per capita in the world." 303

Marc Tucker, education researcher, attributes some of this success to a "broadly shared norm that that the society is collectively responsible for the educational welfare of all of its children." 304 Additionally, Tucker asserts that teacher education programs "draw their students from the top of the talent pool." 305

\section{E. International Takeaways}

This section presented three categorically centralized and one decentralized system of education. While broad categorical classification can be applied, the reality is education systems are more adequately represented on a continuum, with centralized and decentralized at respective ends. Japan, Finland, and Korea do represent centralized systems, but the amount of guidance each national agency provides concerning standards, curriculum, and testing varies greatly. ${ }^{306}$ All three countries have a national curriculum, but the Japanese and Finnish curricula are described as minimally prescriptive curricula or guidelines. ${ }^{307}$ In contrast, Korea

\footnotetext{
298 Id. at 33.

299 Tucker, supra note 12, at 147.

300 SCHMIDT ET AL., supra note 1, at 33.

301 Tucker, supra note 12, at 141 .

${ }^{302}$ Id.

303 Id. at 149 .

${ }^{304}$ Id. at 146 .

${ }^{305} \mathrm{Id}$. at 148 .

306 Strong, supra note 226, at 285; CENTER ON INTERNATIONAL EDUCATION Benchmarking, Top Performing Countries, Finland, Instructional Systems, supra note 247.

${ }^{307} \mathrm{Id}$.
} 
specifies how many minutes must be spent on each content area. ${ }^{308}$ Further, centralized systems typically have multiple, if not annual, national assessments throughout schooling - Finland has only one exam required to graduate from high school. ${ }^{309}$ The point is there are varying degrees of centralization, and debating the merits of broad categorical descriptions dilutes the reality that both central and decentralized systems have worthwhile components.

First, Canada has an almost non-existent federal role, ${ }^{310}$ but the Canadian provinces formed two consortia to essentially normalize the level of rigor and general education objectives between jurisdictions. ${ }^{311}$ Canada effectively created a baseline for understanding, while providing provinces the ability to tailor their curricular guidelines to regional circumstances. ${ }^{312}$ At a fundamental level, this is the same structure and purpose behind the Finnish and Japanese curricula. Both Finland and Japan created general guidelines while providing schools the autonomy to tailor the learning to local circumstances. Despite Japan being classified as a centralized system, the Japanese government publicly criticized the uniform system of education, and announced an educational shift in favor of focusing on the individual child and creativity. ${ }^{313}$ The result was still a baseline of standards provided by the curricular guidelines while permitting local authorities to accommodate for local circumstances. This means all three countries established a baseline of what every student needs to learn, but acknowledged that regional circumstances will inevitably require accommodation.

The distinction in Canada is that the provinces voluntarily chose to norm their curricular standards, whereas schools in Japan and Finland were provided curricular guidelines. However, focusing on the end results, all three systems achieved the same purpose-norming educational objectives and providing a mechanism for regional and circumstantial accommodation. In the U.S., this distinction is irrelevant because CCSS operated identical to Canada in its formulation of voluntary consortia. Further, the U.S. federal government cannot prescribe curricular standards. ${ }^{314}$

Even Korea engaged in this same norming practice, albeit with a more detailed and prescriptive curriculum. Korea still created a defined baseline of what all students are expected to learn, but still promotes respective localities to tailor instruction to regional circumstances. Ultimately, all four

\footnotetext{
308 Center on International Education Benchmarking, Top Performing Countries, South Korea, Instructional Systems, supra note 268.

${ }^{309}$ SAHLBERG, supra note 249, at 125; See also Tucker, supra note 12, at 62.

310 Tucker, supra note 12, at 141.

311 See SCHMIDT ET AL., supra note 1.

$312 \mathrm{Id}$.

313 MEXT Basic Plan, supra note 223.

${ }^{314}$ Department of Education Organization Act, Pub. L. No. 96-88, 93 Stat. 668 (1979).
} 
education systems implemented a baseline of standards while allowing localities to make accommodations for local circumstances.

Two other commonalities among these equitable systems include an emphasis on the quality of teachers and a focus and belief that all students can achieve. The decentralized Canada, just like centralized Finland, recruits their brightest high school graduates into teacher education programs. ${ }^{315}$ Japan also places a large emphasis on teacher quality and professional development just like Canada and Finland. ${ }^{316}$ Korea does focus on teachers, but the shadow system of essentially having two school days for every one day of school is inapplicable to the U.S. system. ${ }^{317}$

The last shared commonality is a commitment to providing equitable education opportunities. All four systems tie education equity to national welfare. Both Finland and Korea reformed their respective approaches to education based on trying to provide more equitable outcomes.

Recognizing that there are far more components in an education system then discussed here, this section highlights that each of these four systems shared commonalities that might otherwise be used as descriptors solely for centralized or decentralized systems. Despite their differences, all four systems defined a baseline of expectations for what all their students need to learn. All four systems consistently focus on teacher quality and development. Finally, all four systems focused on equity and tied educational equity to the national welfare.

\section{RECOMMENDATIONS}

The mere existence of nationalized standards cannot singlehandedly create an equitable and high-performing school system. Aptly stated, "it's a system thing, not a single thing." ${ }^{118}$ Instead, the success or failure of nationalized standards is a product of the cultural, social, political, and legal systems that dictate the implementation and actual use of the nationalized standards.

Researcher Neal McCluskey examined OECD countries "with enough available data” from the 2006 PISA. ${ }^{319}$ McCluskey found that fourteen of the nineteen countries scoring higher than the U.S. had nationalized or regional standards, and five of the nine countries scoring lower than the

\footnotetext{
315 Tucker, supra note 12, at 148; SAHLBERG, supra note 249, at 73.

316 Tucker, supra note 12, at 92.

${ }^{317}$ Ripley, supra note 281.

318 Mona Mourshed, Chiezi Chijioke \& Michael Barber, McKinsey \& Co., How the WORLD'S MOST IMPROVED SCHOOL SYSTEMS KEEP GETTING BETTER 29 (2010), available at http://mckinseyonsociety.com/how-the-worlds-most-improved-school-systems-keepgetting-better/.

${ }^{319}$ McCluskey, supra note 1 , at 9 .
} 
U.S. had nationalized or regional standards. ${ }^{320}$ In light of this, McCluskey's conclusion was that nationalized standards are "no guarantee of superior performance.” ${ }^{321}$ However, missing from McCluskey's analysis of the nineteen countries identified with nationalized standards was the individual context. ${ }^{322}$ It is the contextual, legal, political, social, and cultural climate of each respective country that determines whether nationalized standards are embraced and thereby capable of impacting positive change. In opposition to broad categorical determinations, this Note's analysis of four international systems illustrates that national or regional standards are more appropriately represented on a continuum. This is because standards can range from a minimalistic framework to detailed minute-by-minute expectations. ${ }^{323}$

While national standards are "no guarantee of superior performance," ${ }^{324}$ this Note does not argue that the U.S. should emulate, with perfection, the education system of any other country. It is inevitable that the diversity and size of the U.S. will be objected to when using Finland as a basis for comparison, a country that is significantly smaller and culturally and socially homogenous. ${ }^{325}$ However, "large, geographically dispersed, and culturally heterogeneous nation[s]" like Canada show that norming standards on a larger scale is not only possible, but also beneficial. ${ }^{326}$ Ultimately, the purpose of analyzing Japan, Korea, Finland, and Canada is to demonstrate commonalities between the select few countries that consistently achieve equity and high performance.

As such, in looking at Japan, Finland, Korea, and Canada, commonalities appear in all four systems. Each country has a method of norming standards, be it through a federal agency or voluntary consortia. ${ }^{327}$ Then within those standards, local authorities have the autonomy to accommodate for regional circumstances. ${ }^{328}$ Next, all four systems

\footnotetext{
${ }^{320} I d$.

${ }^{321} I d$.

${ }^{322} I d$.

323 Strong, supra note 226, at 285; CENTER ON INTERNATIONAL EDUCATION Benchmarking, Top Performing Countries, Finland, Instructional Systems, supra note 247; Center on International Education Benchmarking, Top Performing Countries, South Korea, Instructional Systems, supra note 268.

324 McCluskey, supra note 1 , at 9.

325 SAHLBERG, supra note 249, at 8.

${ }^{326}$ Id.

327 Japan: MEXT Basic Plan, supra note 223, at Chap. 3; CENTER ON INTERNATIONAL Education Benchmarking, Top Performing Countries, Finland, Instructional Systems, supra note 247; Korea: Elementary and Secondary Education Act, Act No. 8917, Art. 6, Mar. 21, 2008 (S. Kor.); Canada: See SCHMIDT ET AL., supra note 1.

328 Japan: MEXT Basic Plan, supra note 223, at chap. 3; Finland: SAHLBERG, supra note 249, at 103; Korea: Local Education Autonomy Act, Act No. 8852, art. 1, Feb. 29, 2008 (S. Kor.); Canada: SCHMIDT ET AL., supra note 1, at 33.
} 
emphasize teacher quality and professional development. ${ }^{329}$ Lastly, they all tie education equity and a belief that all children can learn to national welfare. $^{330}$

The predictable options for the U.S. standards-based reform movement include adoption, abandonment, or maintenance of CCSS. As an unintended consequence of NCLB, the pre-CCSS era created a malleable standard for learning expectations. ${ }^{331}$ This consequence of NCLB was highlighted by the Fordham Institute, whose report demonstrated that the national average for all state standards was a C-minus, with "[t]wo-thirds of the nation's K-12 students attend[ing] schools in states with C-, D-, or Frated standards." ${ }^{332}$ Therefore, abandoning CCSS and reverting back to fifty different sets of learning expectations will inevitably continue the trend of inequitable opportunities and mediocre learning outcomes.

Another option is to maintain the course. Forty-three states are moving forward with CCSS and both assessment consortia, PARCC ${ }^{333}$ and SBAC, ${ }^{334}$ are set for implementation in the 2014-2015 school year. However, even states maintaining CCSS still face opposition. ${ }^{335}$ McCluskey argues that nationalized standards may sound great, but fail because implementation requires overcoming the "most politically powerful interests in education." 336 Michael Fullan argues that it is not the "presence of standards and assessment that is the problem." ${ }^{337}$ Instead, Fullan believes

329 Japan: Tucker, supra note 12, at 92; Finland: Tucker, supra note 12, at 51; Korea: Ripley, supra note 281; Canada: Tucker, supra note 12, at 146.

330 Japan: Tucker, supra note 12, at 95; Finland: SAHLBERG, supra note 249, at 103; Korea: OECD, Equity in LeARning Opportunities, supra note 218, at 3-4; Canada: Tucker, supra note 12, at 146.

${ }^{331}$ White House, Reforming No Child Left Behind, supra note 20.

332 Chester E. Finn Jr., Liam Julian \& Michael Petrilli, 2006 The State of State Standards, Thomas B. Fordham Found., Aug. 2006, at 6.

${ }^{333}$ Partnership for Assessment of Readiness for College and Careers, About PARCC, http://www.parcconline.org/about-parcc (last visited Feb. 5, 2014). PARCC member states include: Arizona, Arkansas, Colorado, District of Columbia, Florida, Illinois, Indiana, Louisiana, Maryland, Massachusetts, Mississippi, New Jersey, New Mexico, New York, Ohio, Pennsylvania, Rhode Island, and Tennessee.

334 Smarter Balanced Testing Consortium, Member States, http://www.smarterbalanced.org/about/member-states/ (last visited Feb 5, 2014). SBAC member states include: California, Connecticut, Delaware, Hawaii, Idaho, Iowa, Maine, Michigan, Missouri, Montana, Nevada, New Hampshire, North Carolina, North Dakota, Oregon, Pennsylvania, South Carolina, South Dakota, U.S. Virgin Islands, Vermont, Washington, West Virginia, Wisconsin, and Wyoming.

${ }^{335}$ E.g., Allie Bidwell, More States Seek to Repeal Common Core, U.S. NEWs \& WorLD REPORT (Jan. 31, 2014), http://www.usnews.com/news/articles/2014/01/31/more-statesseek-to-repeal-common-core.

${ }^{336}$ McCluskey, supra note 1, at 21.

337 Michael Fullan, Centre For Strategic Education, Seminar Series 204, Choosing the Wrong Drivers for Whole System Reform 8 (2011), available at http://www.edsource.org/today/wp-content/uploads/Fullan-Wrong-Drivers1.pdf. 
it is the attitude and philosophy behind the standards, which "crush the system by their sheer weight." 338

While "[s]tarting school reform by first deciding what every child should learn strikes most people as only common sense," ${ }^{339}$ there are many variables to consider. The reality is many systemic features have been attributed as the source of equity and high performance ${ }^{340}$ including: nationalized standards, ${ }^{341}$ "the use of achievement data to make decisions about the curriculum, ${ }^{342}$ the use of standardized tests, ${ }^{343}$ the relationship between teacher pay and the pay of a highly skilled worker and overall credentials of teachers, ${ }^{344}$ the decentralization and promotion of local autonomy, ${ }^{345}$ "autonomy in designing curricula and assessments," 346 etc. This means CCSS needs to be viewed as one part of the U.S. reform effort.

Japan, Korea, Canada, and Finland have done more than just establish systems for norming standards. Each country focused on equity, teacher quality, and professional development, while providing the opportunity for local accommodation. Standards represent only one piece in their highly equitable and successful education systems.

Most analogous to the U.S. system is Canada, whose voluntary consortia provide a mechanism for norming standards. Canada's high level of equity and performance are at least in part, attributed to their normed learning expectations. This illustrates that standards provide the "anchor for the development and implementation of coherent education policies.”347 Current domestic education statistics prove what happens when there is no consensus among learning objectives - inequitable outcomes. ${ }^{348}$

Consider what would happen if rather than setting standards at the state level, individual school districts were allowed to set their own standards. The result would likely be a great range of standards within each state, meaning certain districts would set high expectations for their

\footnotetext{
${ }^{338}$ Id.

${ }^{339}$ Rhoads et al., supra note 132 , at 1.

${ }^{340}$ E.g., Arnie Duncan, Sec'y of Educ., Remarks at National Center on Education and the Economy National Symposium: Lessons from High-Performing Countries (May 24, 2011), http://www.ed.gov/news/speeches/lessons-high-performing-countries.

${ }^{341}$ MCKInSEy \& Co., Best Performing Systems, supra note 248, at 51.

342 OECD, What Makes a School Successful? supra note 208, at 78.

${ }^{343} \mathrm{Id}$. at 75.

344 OECD, EQUiTy in LeARning OpPoRTunities, supra note 217, at 4.

345 McCluskey, supra note 1.

346 OECD, What MaKes a School Successful?, supra note 208, at 68.

347 SUPERFINE, supra note 12, at 27.

${ }^{348}$ KansasOpenGov, 8th grade reading proficiency, http://www.kansasopengov.org/ SchoolDistricts/StudentAchievement/NAEPRankingsbyState/8thGradeReadingProficien cy/tabid/2171/Default.aspx (last visited Feb. 5, 2014). (Provides overall proficiency scores for each state and demonstrates that a patchwork of varying standards can yield overall state scores from $46 \%$ of students being proficient in Massachusetts to only $21 \%$ proficient in Mississippi.).
} 
students while others set sub-par standards. This system would be considered inequitable if only certain students in certain school districts were expected to achieve at high levels. Even though each district is going to teach students how to read, write, add, and subtract, the demonstrable effect of the varying standards inevitably forms achievement gaps on statewide assessments. ${ }^{349}$ For this reason, standards are set at the state level so each school district is held to the same state standards and each district knows what their students need to learn to be successful on the statewide assessment. That does not mean every child is subject to a "one-size-fitsall” education; ${ }^{350}$ it means meeting those state standards will look differently in every classroom.

Now, consider the U.S. as a single state with fifty school districts setting fifty different standards yielding drastically different results on statewide assessment (NAEP). ${ }^{351}$ It is still inequitable if only certain students in certain states are expected to achieve at high levels. Identical to individual states norming standards for school districts to meet; CCSS represents a collective state action to norm learning expectations across the country. Identical to the first scenario, this does not impose a "one-size-fitsall”352 education. Learning will still and must look differently in every classroom across the country. ${ }^{353}$

As Korea, Japan, Finland, and Canada demonstrate, different degrees of guidance are required in each country. What works in Korea, a highly prescribed system that specifies "the amount of time to be spent on each subject per school year," ${ }^{354}$ or what works in Finland, which has "one of the least prescriptive curricula," 355 will not produce the same effect in each country. Therefore, U.S. implementation should reflect what the U.S. legal system and the cultural, social, and political climate are ready to accept. The crux of the debate is "choosing a degree of centralization." "356 In this battle between centralized and decentralized control, simply "pushing authority down to lower levels can be as problematic if there is not

\footnotetext{
${ }^{349}$ E.g., KansasOpenGov, supra note 350. (providing overall proficiency scores for each state and demonstrates that a patchwork of varying standards can yield overall state scores from $46 \%$ of students being proficient in Massachusetts to only $21 \%$ proficient in Mississippi.).

${ }^{350}$ Cf. Kohn, supra note 14.

${ }^{351}$ KansasOpenGov, supra note 350.

352 See generally, Kohn, supra note 14.

353 Cf. Center on International Education Benchmarking, Top Performing Countries, South Korea, Instructional Systems, supra note 268; (South Korea has highly prescriptive national standards, but unlike Korea, CCSS does not specify "the amount of time to be spent on each subject per school year.”). This exemplifies the vast differences between alternative models of nationalized standards.

${ }^{354}$ Id.

${ }^{355}$ McKinsey \& Co., Best Performing Systems, supra note 248, at 35.

356 Tucker, supra note 12, at 44.
} 
agreement on what the students need to know and should be able to do.»357

CCSS represents a collective effort by states to establish a common baseline of learning expectations. Japan, Finland, and Canada highlight the need to not only norm learning expectations, but also the importance of allowing local authorities to tailor learning opportunities. The real questions states should be asking are whether the fifteen percent rule provides sufficient local control to accommodate for regional circumstances and how best to utilize their fifteen percent. In the United States, "local autonomy of school districts is a vital national tradition." ${ }^{358}$ CCSS does not encroach upon that autonomy because states voluntarily collaborated and chose CCSS standards. Further, states retain that autonomy by electing how to implement their standards, what degree of local accommodation will be supplemented, and how instruction will look at the day-to-day level.

Forty-three states may be maintaining CCSS, but maintenance alone will not invest school leaders and instructors in the implementation process. Fullan argues that "[h]igher, clearer standards, combined with correlated assessments are essential along the way, but they are not going to drive the system forward." 359 In other words, standards are a prerequisite, but cannot singlehandedly correct educational inequity. Sahlberg agrees, stating "massive systems," like the U.S., "cannot generate on a large scale the kind of intrinsic motivational energy" required for the effective transformation. ${ }^{360}$ Sahlberg states that for these large systems, nationalized standards are great aspirational goals, "but crumble from a strategy or driver perspective." 361

Even the Fordham Institute has acknowledged, "that standards often end up like wallpaper. They sit there on a state website, available for download, but mostly they're ignored." 362 The question then turns to, if standards are part of "the structure necessary for true educational reform," 363 and CCSS provides the "anchor ${ }^{364}$ for all learning opportunities, what drivers, strategies, and attitudes need to surround CCSS?

Japan, Finland, Korea, and Canada show that in addition to norming learning expectations and promoting accommodation for regional circumstances, these countries also emphasize teacher quality, professional development, and tie education equity and a belief that all children can learn to national welfare.

357 OECD, EQUITY IN LEARNING OPPORTUNITIES, supra note 218, at 5.

${ }^{358}$ Mo. v. Jenkins, 515 U.S. at 99 (1995) (citing Dayton I, 433 U.S. at 410).

359 FULLAN, supra note 339, at 8.

360 SAHLBERG, supra note 249 , at 7.

${ }^{361} I d$.

362 Finn Jr. et al., supra note 105, at 2.

363 Stephen L. Gessner, The Changes of Fashionable Education Reform, 11 STAN. L. \& POL'Y REV. 235, 240 (2000).

${ }^{364}$ SuPERFINE, supra note 12, at 27. 
While neither a country's belief system or process for training and developing educators can change overnight, many assert "the quality of an education system cannot exceed the quality of its teachers and principals." 365 Further, despite passing laws stating that even "lowachieving children, can succeed when expectations are high and all children are given the opportunity to learn challenging material," ${ }^{366}$ researchers have found this to not be a uniform belief. ${ }^{367}$ Reform efforts can be "undermined by educators' deficit views and beliefs about the children . . . resulting in efforts which perpetuate disparities in academic outcomes between groups on the basis of culture, language, race, and social class." 368 The reality is that "Placing a high value on education can only get a country so far if the teachers, parents and citizens of that country believe that only a segment of the nation's children can or need to meet high standards." 369

In concluding this Note, it is important to emphasize that highly successful and equitable systems do not rely solely on national standards. Instead, CCSS is one prerequisite piece for creating an equitable system. The history of standards-based reform demonstrates that a voluntary system promoting local autonomy provides the best opportunity to invest all education stakeholders. Because standards-based reform belongs to both Democrats and Republicans, ${ }^{370}$ the focus on CCSS must shift from the apocalyptic-like rhetoric ${ }^{371}$ to the fact that norming common learning expectations is a bi-partisan effort. The debate should instead focus on the level of detail under the CCSS framework; how best to utilize the fifteen percent rule; and the ability to tailor the learning expectations for each

365 OECD, Equity In LEARNING OpPoRTUNities, supra note 218, at 4; Similarly, NCLB is one example of federal law acknowledging the importance of teacher quality. NCLB, supra note 98. ("ensuring that high-quality academic assessments, accountability systems, teacher preparation and training, curriculum, and instructional materials are aligned with challenging State academic standards.”). Another example is aimed at Achieving Equity in Teacher Distribution: "The State will take actions to improve teacher effectiveness . . . in order to address inequities in the distribution of highly qualified teachers between high- and low-poverty schools, and to ensure that lowincome and minority children are not taught at higher rates than other children by inexperienced, unqualified, or out-of-field teachers.” State fiscal Stabilization Fund Program, 58436 Fed. Reg. 74,217 (Nov. 12, 2009).

${ }^{366}$ IASA, supra note 89, § 1001(c).

367 Shernaz B. Garcia \& Patricia L. Guerra, Do We Truly Believe "All Children Can Learn?” Adelante (Spring 2003, Vol. 4, No. 1), http://www.asu.edu/educ/hbli/

publications/adelante/spring03.pdf; $C f$., The National Center for Fair and Open Testing, FairTest Infographic: Common Core: More Tests, But Not Better, FAIRTest (Oct. 6, 2013, 7:44PM) ("raising the bar does not make kids jump higher."), available at http://www.fairtest.org/fairtest-infographic-common-core-more-tests-not-be\#.

${ }^{368} \mathrm{Id}$.

369 OECD, What Makes A School Successful?, supra note 208, at 104.

${ }^{370}$ See SUPERFINE, supra note 12.

${ }^{371}$ Kohn, supra note 14. 
participating state.

We must realize that school leaders and educators represent the lifeblood to education equity. We must consider how to invest more educational leaders through professional development opportunities that provide teachers the necessary time to investigate CCSS, decide how best to help students meet those learning goals, and then design a program for what day-to-day learning should look like in their classrooms. The quality of a school system cannot exceed the quality of its personnel, so we must develop strategies for promoting and advancing the profession in order to retain and recruit more talent. Finally, we must confront the persistent and undermining belief that not all students can achieve at high levels. It is our failure to educate all children that directly results in our educational mediocrity.

CCSS, as a declaration that we believe all students can achieve at high levels, is a prerequisite step toward achieving educational equity. Without a shared baseline of expectations, the U.S. trend of inequity will persist. However, the success of CCSS will always be determined by the cultural, social, political, and legal system to which it belongs. A rising educational tide can raise all boats, including the state of U.S. education, but only if we invest all education stakeholders in implementation. 
